\title{
CRIMINAL RECORDS AND COLLEGE ADMISSIONS: A MODIFIED EXPERIMENTAL AUDIT
}

\section{ROBERT STEWART and CHRISTOPHER UGGEN \\ University of Minnesota}

KEYWORDS: criminal records, collateral consequences, college, education, experimental

This article considers the effect of criminal records on college admissions. Most colleges require criminal history information on their applications, suggesting that an applicant's criminal history could be a significant impediment to accessing the benefits of higher education. We conducted a modified experimental audit to learn whether criminal records affect admissions decisions. Matched same-race pairs of tester applications were sent to a national sample of nonelite four-year colleges, with both testers applying as either Black or White. Within each pair, one application signaled a prior low-level felony conviction when required by the application. Consistent with research on employment, the rejection rate for applicants with felonies was 21/2 times the rate of our control testers. But unlike the large racial differences observed in employment, we find smaller racial differences in admissions decisions. Nevertheless, Black applicants with criminal records who disclosed their records were particularly penalized at colleges with high campus crime rates. We address implications for reentry, racial progress, and the college "Ban the Box" movement. We suggest colleges consider narrowing the scope of such inquiries or removing the question altogether-particularly when it conflicts with the goals of these institutions, including reducing the underrepresentation of students of color.

Robert Stewart is a sociology doctoral candidate at the University of Minnesota. His research focuses on the intersection of criminal stigma, citizenship, and education.

Christopher Uggen is Regents professor and Martindale Chair in Sociology and Law at the University of Minnesota. He is currently writing on reentry from diverse institutions, monetary sanctions, the health effects of incarceration, and genocide.

Acknowledgements:

This research was supported by a grant from the Spencer Foundation. Earlier versions of this paper were presented at the 2017 American Sociological Association Annual Meetings and the 2016 American Society of Criminology Meetings. We are grateful to Mike Vuolo and Ryan Larson for their generous advice and feedback, and to Chelsea Carlson, Eleanor Plaunt, Lesley 
Schneider, Taylor Day, Alex Thibido, Susan Balto, and Emily Kucharski for their invaluable research assistance. Thanks also to the anonymous reviewers and Jody Miller for their careful review and valuable comments. Please direct correspondence to Robert Stewart, Department of Sociology, University of Minnesota, 909 Social Sciences, $26719^{\text {th }}$ Ave S, Minneapolis, MN 55455 (email: stewa640@umn.edu). 


\section{Criminal Records and College Admissions: A Modified Experimental Audit}

Criminal records are a pervasive, acutely restrictive feature of American social life (Shannon et al., 2017; Travis, Western, and National Research Council, 2014). They can limit access to employment (Pager, 2003; Pager, Bonikowski, \& Western, 2009; Uggen, Vuolo, Lageson, Ruhland, \& Whitham, 2014), public assistance (Gustafson, 2011), housing (Thacher, 2008), dating (Evans, 2019; Massoglia, Remster, \& King, 2011), family planning options (Children's Bureau, 2015), and civic participation (Manza \& Uggen, 2006). These restrictions can perpetuate cycles of crime, inequality, and lost opportunity, especially for low-income people and people of color.

Higher education has long been considered an instrument of social mobility and social cohesion in American society, and a potentially compelling mechanism for facilitating desistance (Blomberg \& Pesta, 2017; Ford \& Schroeder, 2010; Runell, 2017). College attendance and completion are associated with lower rates of unemployment and higher relative earnings (Arum \& Hout, 1998; Mayhew, Bowman, Rockenbach, Seifert, \& Wolniak, 2016; U.S. Bureau of Labor Statistics, 2017). Higher education can also unlock access to valued opportunities, develop human capital, and foster civic membership (Becker, 1994; Boli, Ramirez, \& Meyer, 1985; Brown, 2001). Yet, most colleges require applicants to disclose detailed criminal history information as part of the application process, and some evidence suggests that applicants are being rejected on the basis of their records (Custer, 2018; Pierce, Runyan, \& Bangdiwala, 2014; Rosenthal, NaPier, Warth, \& Weissman, 2015; Weissman, Rosenthal, Warth, Wolf, \& MessinaYauchzy, 2010). Thus, the benefits of higher education may not accrue for students with criminal records. 
The increasing scrutiny of criminal records in college admissions is especially consequential for groups most subject to the criminal justice system, particularly young Black males (Brame, Bushway, Paternoster, \& Turner, 2014). Considering the historic underrepresentation of Black Americans in higher education (Davis and Otto, 2016) and their overrepresentation in justice-involved populations (Kaeble \& Glaze, 2016), criminal history disclosure requirements could raise additional barriers to racial progress, student learning, and democracy. Officials cite campus safety as the principal reason for requiring criminal history information, especially in the aftermath of widely publicized on-campus incidents (Dickerson, 2008; Pierce et al., 2014). Significantly, however, these questions may be ill-suited for predicting future criminality (Runyan, Pierce, Shankar, \& Bangdiwala, 2013) and reducing campus crime rates (Olszewska, 2007).

The use of criminal records in the college admissions process has rarely been considered in criminology, so little is known about the prevalence of criminal history disclosure questions and the degree to which a criminal record might affect college acceptance. This article provides the first estimates of the effect of a criminal record on college admissibility of young men, as well as race differences in these effects. We begin by reviewing research on the relationship between higher education and punishment, discrimination on the basis of criminal records, and the use of criminal records in the higher education context. We then discuss the likely impact of policy remedies such as the Ban-the-Box movement before asking an empirical question with policy implications: whether and how felony records affect college rejection rates. We use a modified experimental audit method to generate a specific estimate of the impact of a single felony conviction for robbery or burglary when applying to non-elite four-year colleges, and briefly highlight other forms of differential treatment that applicants with records encountered in 
our study. We find that while a felony record is not a categorical disqualifier, it can become a considerably limit college access. We conclude by placing these results in the context of research on employment discrimination and the nascent "ban the box" movement for colleges that parallels recent "fair chance" legislation governing job applications.

\section{PUNISHMENT AND EDUCATION}

A considerable research literature examines the effects of employment on desistance and recidivism (see, e.g., Uggen, 2000; Laub and Sampson, 2001; Pager, Western, and Sugie, 2009; Berg and Huebner, 2011; Skardhamar and Savolainen, 2014; Denver, Siwach, and Bushway, 2017), but there have been very few rigorous studies that focus on the relationship between higher education and desistance/recidivism, particularly for those not in prison. Existing observational and quasi-experimental studies of prison education have generally found that higher education (whether in or out of prison) is associated with positive outcomes, including lower recidivism and higher employment and earnings (Duwe \& Clark, 2014; Lockwood, Nally, Ho, \& Knutson, 2012). With respect to recidivism, studies that employ propensity score matching to adjust for selectivity have generally found that prison-based college programs reduce recidivism measured by rearrest, reconviction, reincarceration, and revocation (Duwe \& Clark, 2014; Kim \& Clark, 2013). A meta-analysis of over 50 studies estimated that participants in prison education programs were 43 percent less likely to recidivate than non-participants (Davis, Bozick, Steele, Saunders, \& Miles, 2013). Although these outcomes speak to prison education, they are of limited usefulness because people who are incarcerated are at much higher likelihood of reoffending than a general population sample of college applicants. Still, this research encourages further study of education and post-criminal justice involvement and its link 
to employability and desistance from crime. Given the public and policy interest in higher education, desistance, and employability, an examination of barriers to college is merited.

Higher education may facilitate desistance by serving as a bridge to cultivate social bonds with prosocial peers and role models, develop self-efficacy, and acquire human capital (Becker, 1994; Brown, 2001; Ford \& Schroeder, 2010; van Dinther, Dochy, \& Segers, 2011). Further, education likely reduces crime by increasing earnings and the quality of employment (Arum \& Hout, 1998; Carnevale, Rose, \& Cheah, 2013; Mayhew et al., 2016; U.S. Bureau of Labor Statistics, 2017), which could help counterbalance the negative effects of criminal justice involvement on employment, earnings, and mobility (Western, 2002).

Nevertheless, just as in the labor market, people with criminal records may be denied access to the benefits of higher education precisely because of their criminal records. A criminal record generally acts as a "negative credential" that restricts opportunities in much the same way that a college degree acts as a "positive credential" to expand opportunities (Gaddis, 2015; Pager, 2003). Where a college degree might help to signal honesty, work ethic, and responsibility to an employer, for example, a criminal record might signal dishonesty, dangerousness, and irresponsibility (Kurlychek, Brame, \& Bushway, 2006; Lageson, Vuolo, \& Uggen, 2015), constraining job opportunities. Thus, if a criminal record poses a similar challenge to higher education access as it does in the labor market, then prior criminal justice involvement could limit educational attainment and its beneficial effects on desistance and the transition to adulthood. As Lovenheim and Owens (2014) found by exploiting a federal policy change that restricted financial aid for a certain time period for people convicted of drug felonies, while there was little evidence the policy change was an effective deterrent, there were notable consequences for affected students who experienced a delay in college enrollment and attainment, likely 
stunting potential growth in their lifetime earnings. Consequently, barriers to college access that do not serve a sound public safety interest likely cause considerably more harm than they prevent.

\section{CRIMINAL RECORD DISCRIMINATION}

The collateral consequences of a criminal record, particularly a felony-level record, have received great attention in institutional domains such as the labor market (Pager, 2007a), the political system (Manza \& Uggen, 2006), and parenting (Wakefield \& Wildeman, 2013). Although typically studied in isolation, these consequences are experienced as a system of disadvantage (Wheelock, 2005) in which legal and social restrictions are broadly and indiscriminately "piled on” (Uggen \& Stewart, 2014). In the labor market, for example,

researchers typically assess the effects of criminal records on hiring decisions, but such records also constrain the opportunity to apply for many positions, whether through formal prohibitions on occupational licensing or employment in certain industries or through informal access to educational opportunities and credentials (May, 1995).

\section{LABOR MARKET CONTEXT}

Experimental research has convincingly established that applicants with criminal records face significant discrimination during the application stage of the hiring process, in part due to these criminal history questions. Schwartz and Skolnick (1962) were among the first to show how a conviction reduces "positive responses" [i.e. callbacks] from employers and leads to lasting "status degradation." Devah Pager and colleagues continued this work with rigorous, inperson audit studies testing the effect of a major felony drug conviction (Pager, 2003, 2007a; 
Pager, Bonikowski, et al., 2009), finding a significant reduction in callbacks for applicants with felony records compared to their nearly identical control applicants. As Pager summarizes the results (2007a:147), a criminal record represented "one serious strike" against White applicants but "almost total disqualification" for Black applicants. Using a similar in-person audit design, Uggen and colleagues observed a similar pattern in testing the effect of low-level arrest records, which reduced the callback rate by about 15 percent for Black applicants and 10 percent for White applicants (Uggen et al., 2014).

More recently, Agan and Starr (2017) conducted a large-scale correspondence audit in New York and New Jersey. Their findings again confirmed the negative impact of a criminal record (in this case a low-level drug or property felony) on the first stage of the employment process, reducing callback rates by nearly 40 percent. Contrary to the standard racial hierarchy (in which the White applicant serves as the benchmark) found by Pager et al. and Uggen et al., however, Agan and Starr found almost no racial differences in callback rates, which may be due to differences in how race is conveyed in correspondence studies (Decker, Ortiz, Spohn, \& Hedberg, 2015).

\section{HIGHER EDUCATION CONTEXT}

Paralleling the hiring process, most colleges ask applicants for criminal history information during the application process. A survey of two-year and four-year admissions departments by the Center for Community Alternatives found that 81 percent of private and 55 percent of public colleges have some type of criminal history question (CHQ) on their applications (Weissman et al., 2010). In preparation for this research, we reviewed freshman undergraduate applications for the fall 2015 entering class for every U.S. four-year, non-profit, 
non-specialized college listed in Barron's Profiles of American Colleges 2016 (Barron's PAC) that was accessible (a total of 1,350 colleges, see Table 1) and found comparable results. Barron's PAC is a popular college guidebook that employs an admissions competitiveness ranking system that is widely used in education research (see, e.g., Alon and Tienda, 2005;

Carini et al., 2003; Monks, 2000). Nearly 80 percent of private colleges and 58 percent of public colleges required applicants to answer CHQs on their applications that season. Further, colleges that have more competitive admissions are more likely to feature CHQs on their applications, ranging from almost 90 percent for colleges classified as "Most Competitive" to just under 34 percent for "Non-Competitive." Colleges with higher crime rates, colleges that consider race/ethnicity in their admissions process, and suburban colleges are also more likely to include CHQs on their applications. In a multivariate analysis that includes each of these factors (available from authors), more competitive institutions, private colleges, and those with higher Black undergraduate enrollments were significantly more likely to ask about criminal records. Like Vuolo, Lageson, and Uggen (2017), we found considerable variation in how colleges asked about criminal records on their applications, including interests in different levels of offense (any conviction, felonies, juvenile offenses, certain offense-types) and phases of the justice system (charge, arrest, conviction, supervision status).

[Table 1 about here.]

The point at which criminal history information is considered in the admissions process varies, including before, during, or after considering academic admissibility (Weissman et al., 2010; Rosenthal et al., 2015). Most institutions require students to submit additional information 
if they disclose a prior criminal record, which could include a letter of explanation, multiple letters of recommendation, a criminal background check from a third-party vendor (at the applicant's expense), and an official criminal history report from their state's criminal record custodian, which often contains information that is publicly accessible (e.g., convictions) and information that is not (e.g., arrests without convictions, juvenile adjudications) (Weissman et al., 2010). Collecting and submitting these additional materials can be time-consuming and burdensome, and many applicants choose to drop out of the process at this point (Rosenthal et al., 2015).

To be sure, colleges and universities ask their applicants about criminal history information for a variety of reasons, but publicly and in surveys college administrators have suggested these questions are primarily grounded in concerns about campus crime and safety or at least the perception of campus crime and safety (Jaschik, 2017; Lantigua-Williams, 2016). At least half of the respondents of a 2011 survey of administrators at colleges that ask about criminal records said that reducing violence, protecting against liability, and reducing illegal drug use were very important reasons why they require criminal history information (Pierce et al., 2014). However, there is no evidence that criminal history questions on college applications are effective tools for reducing campus crime (Olszewska, 2007; Runyan et al., 2013; Pierce et al., 2014). A 2007 study that controlled for various institutional characteristics, for example, found no statistically significant difference in rates of campus crime at colleges that ask about criminal records compared to colleges that do not ask (Olszewska, 2007). More recent work on college crime reports before and after state-implemented student background check requirements similarly found little effect on campus crime (Hughes, Elliott, \& Myers, 2014). 
Further, the usefulness of criminal history application questions for soliciting accurate information has not been demonstrated empirically. For the vast majority of institutions, these questions rely at least initially on self-reported information from the applicant (Weissman et al., 2010; Pierce et al., 2014). As of this writing, responses are usually only verified if the applicant indicates that they do have a prior criminal conviction (Rosenthal et al., 2015). Otherwise, the application continues to move through the process unfettered. Thus, these questions are susceptible to inaccurate responses and may not be predictive of future criminal behavior or college misconduct. ${ }^{1}$ Runyan et al. (2013), for example, surveyed graduating seniors at a large public university and conducted criminal background checks on a subsample. When they compared those data to each student's response to the criminal history question on their undergraduate application, they found that most students did not accurately disclose their criminal records. They did find that students with prior criminal records were somewhat more likely to engage in misconduct while in college (primarily related to marijuana or alcohol use), but application CHQs overall were poor predictors of that college misconduct. However, Runyan et al. did not include students who were rejected on the basis of their pre-college criminal records nor students who left college before graduation, so the question of the predictive capability of criminal history screening questions in college admissions remains unclear.

\footnotetext{
${ }^{1}$ A University of North Carolina (2004) task force found that of the 532 campus crimes reported between 2001 and 2004 in which a student was named as a suspect, only 21 had a prior criminal history. However, only 8 of those 21 students had disclosed their criminal record on their application. When UNC later expanded their use of background checks, there was no reduction in campus crime (Hughes, Elliott, \& Myers, 2014).
} 
Apart from direct concerns about campus crime, college policies may also be motivated by considerations of reputational and legal risk. To the best of our knowledge there has not yet been a successful "negligent admissions" case in which a college was sued for admitting a student with a criminal record who later went on to victimize another student on campus (Dickerson, 2008; Ramaswany, 2014). However, this is a particularly complicated area of tort law involving, among other issues, a college's duty to protect students, faculty, and staff, and whether a person with a criminal record is a foreseeable risk (Dickerson, 2008). This legal uncertainty coupled with relatively high campus crime rates - or the perception of high crime rates - in an era of penal risk aversion and mitigation may provoke colleges to take a hardline approach to students with records and lead to significant discrimination in admissions, just as employers discriminate in the labor market, where negligent hiring suits are a more realistic possibility (Pager, 2007a; Todd, 2004). Thus, evaluating the role of campus crime and potential risk in higher education admissions with respect to applicants with criminal records would be instructive.

\section{BAN THE BOX GOES TO COLLEGE}

The labor market disadvantages of criminal records and their racial implications have motivated at least 30 states and 150 cities and counties since 1998 to enact "Ban the Box" (BTB) policies (Avery \& Hernandez, 2018). The basic BTB policy prohibits some or all employers in a given jurisdiction from inquiring about an applicant's criminal history on the initial application, theoretically preventing employers from categorically rejecting applicants with records with little to no consideration. But these policies do often allow the employer to make those inquiries in later stages of the hiring process. The logic underlying such policies assumes that applicants with 
records will fare better if they are given some initial consideration and a "fair chance" to explain their criminal record during the interview phase (Avery and Hernandez, 2018; Uggen et al., 2014).

BTB advocates argue these policies could help to close the racial employment gap. According to estimates by Shannon et al. (2017), about 23 percent of Black adults overall and 33 percent of Black adult males have felony records, compared to 8 percent of adults and 13 percent of adult males in the overall population, respectively. Thus, Black adults are more acutely affected by criminal record questions and removing these questions could reduce the effect of this disadvantage. Research on the policy's impact, however, has raised troubling questions about potential statistical discrimination when "the box" is banned. Recent work suggests that BTB policies might exacerbate some forms of racial discrimination (Agan \& Starr, 2018; Doleac \& Hansen, 2016; Vuolo, Lageson, \& Uggen, 2017). Agan and Starr (2018), for example, tested the interaction between felony record and race in correspondence audits conducted before and after BTB in New York City and New Jersey. Following implementation of BTB, the BlackWhite gap in callbacks at companies that removed the box from their applications grew six-fold compared to the pre-BTB gap (43 percent and 7 percent, respectively). The implication is that the lack of direct criminal history information may have harmed Black male applicants without records as they had fewer opportunities to overcome employers' erroneous assumptions regarding their criminality (Agan \& Starr, 2018; Phelps, 1972; Vuolo et al., 2017). Any BTB policy initiative should therefore seriously consider potential unintended consequences for those with and without criminal records, at least with respect to the employment context.

In recent years, the BTB movement has expanded to the higher education context. Based on concerns regarding barriers to reintegration and the racially disproportionate effects of the 
justice system, the Obama administration released a report urging colleges to reevaluate and reconsider their admissions policies regarding criminal history questions (U.S. Department of Education, 2016). Later that same year, the State University of New York System's Board of Trustees (SUNY) voted to remove the criminal history box from SUNY's application (Jaschik, 2016). Louisiana became the first state to pass and enact a college BTB bill in 2017 for its public colleges, followed by Maryland wherein the Maryland General Assembly overrode a veto in early 2018 to enact its own college BTB bill (Dresser, 2018; Newhouse, 2017). And in August of 2018, The Common Application (2018) announced that it would no longer include a criminal history question on its main application component, though members colleges can continue to require criminal history information on their supplemental applications.

BTB reforms in the labor context have generally involved shifting the point at which an employer is permitted to inquire about prior criminal history from the application stage to a later stage in the process, such as the interview. But the context of higher education, which typically involves a single decision point - the admissions decision - rather than several stages as in the hiring process, might make delaying asking more complicated. Instead, most college BTB reforms have either done away with the questions entirely or narrowed the contexts wherein a college would request criminal history information, such as on campus housing applications or when applying to certain programs where a criminal record could become a barrier. In light of these reforms and the unintended consequences of BTB policies in the employment sector (e.g., Agan and Starr, 2018), it is increasingly urgent to learn how banning the box from college applications would affect applicants with and without criminal records. 


\section{THE AUDIT METHOD AND ESTIMATING DISCRIMINATION}

Audit studies have become an increasingly important methodology in the social sciences, particularly in discrimination studies (Pager, 2007b; Gaddis, 2018b). Randomized experiments have far greater capacity to detect causal relationships than alternative approaches such as covariate adjustment analysis of survey data (Neumark, 2018). Because audits are typically conducted in real-world environments, they also tend to have greater external validity than labbased experiments. The basic audit design typically refers to a field experiment where an attribute is randomly assigned to one tester within a pair of very similar or near identical testers to test the effect of that that attribute on the outcome of interest (Gaddis, 2018a).

Researchers have used the audit method to detect discrimination in diverse contexts, including housing (Ghoshal \& Gaddis, 2015; Turner, 1999; Wissoker, Zimmermann, \& Galster, 1998; Yinger, 1998), medical decision-making (Schulman et al., 1999), and commercial transactions (Ayres \& Siegelman, 1995; Ridley, Bayton, \& Outtz, 1989). Perhaps the most notable application of audit methodologies has been in the area of labor market discrimination with respect to gender (Neumark, Bank, \& Van Nort, 1996), sexual orientation (Tilcsik, 2011), race (Bertrand \& Mullainathan, 2004; Pager, Western, et al., 2009), college credentials (Gaddis, 2015), and interactions among these and other factors (Gaddis, 2015; Pager, Bonikowski, et al., 2009). Recently, the audit method has been particularly effective in estimating criminal record discrimination in the labor market, particularly along dimensions of race, gender, and severity (Pager, 2003; Pager, Bonikowski, et al., 2009; Galgano, 2009; Uggen et al., 2014; Baert \& Verhofstadt, 2015; Ahmed \& Lång, 2017; Agan \& Starr, 2018), and in housing (Evans \& Porter, 2015; Evans, 2016; Furst \& Evans, 2017). 


\section{DESIGN AND APPROACH}

Based on this literature, we designed a study to answer the following research questions:

(1) whether and to what extent four-year colleges discriminate on the basis of criminal records;

(2) whether such discrimination varies by race and institutional context, including the local crime rate; and, (3) how a Ban-the-Box strategy to remove criminal records questions from college application forms might affect admissions and racial inequality. ${ }^{2}$

To our knowledge, this study is the first audit of criminal records in higher education. The admissions context is distinctive in four fundamental ways that guide our research design. First, third-party testing services (e.g., ACT, SAT) and high schools are important intermediaries in the college admissions process (Klasik, 2012). To apply to nearly any U.S. college, applicants must request that official documentation (e.g., transcripts) be sent directly from their high schools. Many colleges, especially at the baccalaureate level, also require applicants to request that college entrance examination scores (e.g., ACT, SAT) be sent directly from their testing agencies. Thus, audits in the higher education context can either (1) attempt to fabricate this information, or (2) recruit real people and use their actual educational background information. We chose the latter option, such that the testers in this project present real rather than fabricated educational histories.

${ }^{2}$ We initially planned to include female testers and testers in other racial and ethnic categories, but revised this plan in view of budget limitations, difficulties identifying and securing suitable matched pairs, and the possibility of detection when submitting matched pairs of applicants from groups that are underrepresented on many of our sample campuses. 
Second, the applicant pool in higher education fills hundreds or thousands of seats rather than the small number of positions available in most employment contexts. We therefore measure final acceptance as the primary outcome, rather than initial expressions of interest or callbacks. Third, admissions decisions are likely to be made by a group or team rather than a single authority in the hiring context (Stevens, 2009). This structural difference might lead to greater risk aversion in accepting stigmatized applicants, although both environments are currently characterized by great legal uncertainty (Lageson et al., 2015). Finally, in contrast to the vast majority of research on race-based admissions and affirmative action, we examine admissions practices across a diverse range of non-elite four-year institutions. As Hirschman and Berrey suggest, much prior research "tends to infer the logic of the entire field of higher education from analyses of the admissions practices of elite institutions" (2017, p. 449), but we instead focus on the both 80 percent of four-year colleges that serve a wider array of students, geographies, and interests.

\section{“MODIFIED” AUDIT DESIGN}

The college admissions context is an environment in which complete fabrication, as is standard with the traditional audit design, is simply not realistic. Thus, we endeavored toward a "modified" audit design - modified because it uses real records that are matched as opposed to totally fabricated records - that balances two main goals. First, we prioritized modal representativeness by designing a project that emulates the real world as closely as possible. The second goal flows from the first in balancing goals of representativeness with realistic and practical significance in order to produce meaningful results. We sought to determine whether 
criminal record discrimination occurs in the admissions process and whether that discrimination is mediated by race.

The "modified" design presents opportunities for experimental research in contexts not otherwise available to the traditional audit design. While labor market and housing audits have typically focused on the initial phase of the application process, proceeding further in the process with fabricated materials is likely to raise suspicion and/or may not be possible when official documents are required. By incorporating real records that would pass the application review process with a much lower likelihood of detection, researchers have the opportunity to gain access to later stages of the process that otherwise might not be available or realistic with fabricated materials. Going further in the application process presents opportunities for collecting primary data for additional analyses, such as direct communications and correspondence generated as part of the process. We outline below how we proceeded through the design process for this field experiment of college admissions.

\section{Tester Recruitment and Matching}

The first and most crucial step in our design process was to determine the makeup of our testers. As mentioned above, it would not have been feasible to fabricate educational credentials. Most colleges require high school transcripts be sent directly from the high school. And thirdparty standardized testing companies (e.g., ACT or SAT scores), whose legitimacy is heavily embedded in the validity of their test scores, would not be willing to create fake score reports. We would also argue that it would have been unethical to assign felony records to these participants, as some colleges seek official documentation of those criminal records. Therefore, we recruited real people to serve as the basis of our tester profiles and submitted tester 
applications using their actual high school transcripts, actual test scores, and actual criminal records.

We began recruiting in early 2015 . For both profile conditions, we sought testers who had finished high school, taken the ACT, and were in their late teens or early twenties. Additionally, potential "Record testers" had to have a single felony conviction and "No Record testers" had to have no criminal history. The testers agreed that they would not actually attend the colleges in the sample, and we specifically sought testers who were not considering applying to any college within our sampling frame. We used several recruitment methods, including Craigslist ads, local and student newspaper ads, email announcements, word-of-mouth, and partnerships with local nonprofits. Those interested were directed to an online sign-up form which asked basic background questions (name, age, contact information, graduation year, high-school GPA, ACT score) and criminal history information. After approximately 11 months, we had a list of approximately 25 possible treatment testers and more than 450 possible control testers who met the basic qualifications.

From those two lists, we began the matching process. Knowing that it would be impossible to perfectly match testers on observable and unobservable characteristics that could bias the results (Heckman, 1998), we created matches that were purposely asymmetrical but would be analyzed as if they were equivalent. In each matched pair, the Record tester is slightly better qualified academically relative to the No Record tester (signaled by a slightly higher GPA and/or ACT score) while other features, such as high school rigor, high school profile, and applicant age were comparable. The assumption, then, is if one were to set aside the felony and compare the applications head-to-head, the Record tester application would be slightly more likely to be admitted than the No Record counterpart. Our matched pairs were reviewed by six 
admissions counselors at different colleges to confirm that, but for the felony, our record applicants would be the more competitive of the pair. We also calculated admissions index scores using formulas from seven different college systems to further ensure that, within each pair, the Record testers were always the better of the two students on paper. This asymmetrical approach will thus provide a conservative estimate of discrimination by design.

We successfully recruited two well-matched pairs of male testers, ${ }^{3}$ one pair of B- students and one pair of C students, and were within a year of each other in age (early 20s). The Record testers' academic qualifications were slightly higher than their counterparts in terms of GPA (approximately +0.2 grade points), ACT ( $+1-2$ composite points), and class rank (approximately $+10-15$ percentage points). Both Record testers were serving five years of unsupervised probation for felony convictions when they were 18 (one for a single count of aiding and abetting simple robbery and the other for a single count of burglary).

Following the matching process, we assembled application profiles for each tester. Each profile included tester-specific information (e.g., high school transcript, ACT score information, and other information that we would not be able to assign) and unique contact information (e.g., unique email addresses, street addresses, phone numbers with voicemail boxes, and social media accounts). We then created sets of generic profile attributes that could be randomly assigned within each pair, including extracurricular activities, volunteering information, and employment information.

\footnotetext{
${ }^{3}$ We also recruited a well-matched pair of female testers, but one member of the pair withdrew from the study before we could enter the field.
} 
Essays were also required at several colleges. We approached writing the essays as if they were vignettes in a very simple factorial experiment. We identified four widely used essay prompt themes and wrote pairs of essay responses for each theme, engaging similar topics in both essays. While we want to be cautious about revealing information that might compromise our testers, these essay responses generally focused on learning from bad choices. We then randomly assigned the essays within each essay pair to the Record tester or the No Record tester and swapped in relevant information where appropriate.

\section{Signaling Race}

Correspondence audits testing race must inevitably determine how best to effectively convey race for the given context. Where race cannot be signaled directly on application forms, researchers attempt to signal it indirectly through use of race-typed names, physical presentation or photos of applicants, membership in race-typed clubs (e.g., the Black Student Association), and other markers thought to be associated with race (Pager, 2007b). The U.S. Department of Education requires colleges that receive federal financial aid to ask a set of voluntary race and ethnicity questions on the application. In this context, we can directly signaled race by selecting either "Black or African American" or "White," though we cannot directly observe how it is used in their deliberations. Importantly for our purposes, the names of our testers were not particularly indicative of a particular race group and were unlikely to convey significant race signals on their own (see Appendix 1 where we follow the guidance of Gaddis [2017]), so we randomly assigned race to each tester pair-college combination regardless of the actual race of participants. That is, the same tester pairs both checked "White" at one subsample of colleges and both checked "Black" at another subsample of colleges.

\section{Signaling Criminal Record}


Unlike previous audits that tested the effect of criminal records in the labor market context, we only conveyed the criminal record when asked on the college application. It would be highly unusual for an applicant to offer such potentially stigmatizing information unprompted in the higher education context. In most cases, colleges with criminal record questions would require additional materials relating to the criminal record. The specific additional materials requested varied widely from college to college, ranging from short explanations to several multi-page documents. The typical request for additional information was a written explanation of the incident (which the research team prepared), official copies of police or court records, and an official criminal history report (that included public and private data) from the state criminal record custodian. Other documents that we submitted included letters of recommendation (which we fabricated), a letter from a probation officer or other criminal justice official, and a background check from a third-party vendor (typically at the applicant's expense).

\section{SAMPLE}

Defining our sample required several design choices. To guide our decision-making, we prioritized external validity. Thus, we chose to focus on four-year colleges rather than community colleges or other two-year institutions, which were much less likely to request criminal history information than four-year colleges (Weissman et al., 2010) and offer fewer benefits in terms of lifetime earnings and employability compared to four-year colleges. We similarly excluded highly specialized colleges (such as colleges of art or music and military academies) because of their unique nature.

Our universe of possible colleges $(n=1,350)$ consisted of U.S. four-year colleges, stratified by the selectivity criteria noted in Barron's Profiles of American Colleges (Barron's 
College Division Staff, 2015), a popular college guidebook. Barron's competitiveness index, which is derived from a formula that includes various measures of SAT/ACT medians and scoring, high school class rankings, and acceptance rates of previous incoming classes, is widely used in academic and policy research for comparing higher education institutions. Barron's competitiveness index includes six levels ranging from "Non-Competitive" to "Most Competitive."

The wide variation in college selectivity compelled us to choose whether to draw our sample from the entire universe of four-year colleges or from a select range of colleges. Because it would have been atypical for our applicant testers to apply to elite or upper-tier institutions (Bowen \& Bok, 2016; Roderick, Coca, \& Nagaoka, 2011) - particularly those colleges where our testers would not have met the minimum academic requirements or would have been significantly below the ACT $25^{\text {th }}$ percentile for the previous year - we excluded colleges ranked in the top two tiers of admissions competitiveness ("Most Competitive" and "Highly Competitive"). Removing the most competitive colleges left a possible sampling frame where our testers had a reasonable chance of being accepted. This choice follows the logic employed by many audits of the labor market (Pager, 2003; Pager, Bonikowski, et al., 2009; Uggen et al., 2014) where researchers had testers apply for entry-level positions rather than executive or management positions.

Our final sampling frame included 1,163 institutions that served $82.1 \%$ of all four-year college students. To this list of colleges, we added 2015 institutional data from the NCES Integrated Postsecondary Education Data System and drew two initial representative random samples of 200 colleges for each race condition. However, we assumed that unanticipated complications (such as document requirements we could not satisfy or late transcript requests) 
would likely prevent us from completing some portion of the applications, thus reducing the total sample. The initial samples were representative of the sampling frame on four key variables: (1) whether there was a criminal history question (dichotomous), (2) selectivity (more competitive, competitive, less competitive), (3) public or private (dichotomous), and (4) percent of undergraduate enrollment who identified as White (as a proxy for undergraduate campus diversity). Each subsample was randomly assigned to one of two pairs of applications ([1] Black/no-record and Black/record or [2] White/no-record and White record). This design allows us to calibrate the effect of a criminal record for Black and White applicants.

\section{ESTIMATION}

As recent methodological work suggests, the traditional paired design in audit studies is not necessarily optimal in all settings (Vuolo, Uggen, \& Lageson, 2016, 2018). Our design and statistical models closely parallel those of recent employment audits, particularly the research of Devah Pager (2003), Mike Vuolo (Uggen et al., 2014; Vuolo et al., 2016), and S. Michael Gaddis (Gaddis, 2015). Each record and race contrast can be considered a separate experiment (Cox, 1958). We have a within or matched design on the criminal record signal and a between design on the race signal (Gaddis, 2018a; Lahey \& Beasley, 2018) Fear of arousing the suspicion of admissions officials or introducing potential bias led us to opt for a mixed within/between design across characteristics rather than a full (4 applications per institution) within design (Gaddis, 2015; Weichselbaumer, 2015, 2016; Phillips, Forthcoming).

Our primary dependent variable is the admission decision: accepted or not accepted. To be included in our analyses, both paired tester applications must be categorized as either "accepted" or "not accepted," thus forming a complete pair. If the admissions decision for a 
tester application is either accepted or accepted with conditions, it is categorized as "accepted." If the application is rejected, waitlisted, the decision is deferred, or if the college did not provide a decision by the beginning of the fall semester, it is categorized as "not accepted." An application that had any other outcome is deemed incomplete and its pair is not included in our analyses.

From December 2015 to May 2016, we submitted 800 applications at 400 4-year colleges, with each tester pair assigned as White or Black for half the audits. This allows us to determine the likelihood of college acceptance for each condition-race pairing (White record/White no-record; Black record/Black no-record). ${ }^{4}$ Each pair applied to a different set of colleges as Black and as White. We left the field in September 2016 with 280 complete pairs (150 Black, 130 White). Reasons for a tester application to be categorized incomplete include documentation required that we could not provide (16.6 percent), researcher error (2.6 percent), a formal interview requirement (1.5 percent), and website issues ( 0.7 percent). Because we left the field with less than our entire sample of 400, the estimates we present below could be interpreted as a local average treatment effect.

Table 2 shows how our audit sample ( $\mathrm{n}=280)$ compares to our sampling frame ("Very Competitive to Non-competitive"; $n=1,171)$ and the larger scope of four-year colleges $(n=1,350)$.

\footnotetext{
${ }^{4}$ We did not send White and Black applications to the same institutions due to the increased probability of detection and because the power to detect differences would be diminished if the pairs were further divided into the 4 groups necessary to conduct such an experiment. Because our primary research interest concerns the treatment effects of felony-level records, we designed the study to maximize the power to detect these effects. The absence of interracial within-college covariance in this design, however, means that our results regarding racial discrimination rely on randomized non-paired data rather than paired comparisons (cf. Pager, Bonikowski, and Western, 2009).
} 
The audit sample is similar to our sampling frame with a few notable exceptions. Colleges in the audit sample were less likely to consider race in admissions, were more likely to be in rural settings, and had slightly whiter undergraduate populations.

[Table 2 about here.]

\section{STATISTICAL MODELS}

We include a slate of institutional characteristics and audit characteristics to adjust for between-college heterogeneity. For each college, we include whether criminal history disclosure was an application requirement $(0=\mathrm{no}, 1=\mathrm{yes})$, institution type (public or private), collapsed admissions competitiveness categories (Barron's "Noncompetitive" and "Less Competitive" = less competitive, Barron's "Competitive" = moderately competitive, Barron's "Very Competitive" = more competitive), location (rural/town, suburban, urban), institution size (very small, small, medium, large), and whether the college considers race and ethnicity in admissions (according to responses to The College Board's Annual Survey of Colleges). We also include continuous measures that reflect the makeup of the undergraduate student population, including percent receiving Pell grants (to indicate student socioeconomic status), percent Black and percent White (to indicate student body diversity), and 6-year graduation rate. For audit characteristics, we include which tester pair the applicant belongs to (that is, the B-pair of the C pair), whether the applicant applied first within the pair to that college, and the audit order in which the colleges received applications.

We are also interested in whether there is a relationship between the perception of campus safety and applying to college with a felony record. We thus include a dichotomous 
measure of campus crime rate as a publicly available indicator of the perception of campus safety derived from data reported as required by the Clery Act, a consumer protection law designed to provide crime statistics and information about U.S. colleges to prospective students. Colleges with 10 or more total reported criminal offenses over the previous 3-year period (20132015) were coded as "high crime" and fewer than 10 reported offenses as "low crime" (Sloan III, Fisher, \& Cullen, 1997; Hart, 2007; Hughes et al., 2014). Admittedly, Clery Act crime data are flawed indicators of campus safety because they are based on self-report and internal college processes that do not tell us how these data are produced at each institution (Fisher, Hartman, Cullen, \& Turner, 2002). Nonetheless, college leaders are sensitive to metrics and relative rankings, often despite their shortcomings or validity concerns, and Clery crime data are a common, publicly reported indicator to which university administrators and policymakers often attend (Sauder \& Lancaster, 2006). Thus, colleges with higher reported crime rates may be more cautious when reviewing applicants with criminal records. We incorporate the crime rate measure as a standalone covariate and as an interaction term with felony record, which we discuss in more detail below.

Tester application pairs successfully applied as Black to 150 randomly assigned colleges and as White to 130 randomly-assigned colleges. Each college represents a cluster with two repeated measures, one no-record application and one record application. Responses within clusters are therefore positively correlated, so treating within-cluster observations the same as between-cluster observations would be problematic (Agresti, 2013, p. 489).

For bivariate analysis of the dichotomous acceptance outcome, we use McNemar's (1947) test of difference for matched pairs. Following Agresti (2013, pp. 413-14, see also Uggen et al. 2014), $\pi_{a b}$ denotes the population probability of outcome $a$ (accepted) for the first tester 
and outcome $b$ (not accepted) for the other tester at the same college. The count of the number of pairs in each cell is represented by $n_{a b}$, and the sample proportion is represented by $p_{a b}$. The test assesses the hypothesis of marginal homogeneity, or equality between cells in which testers had different outcomes: $H_{0}: \pi_{1+}=\pi_{+1}$. McNemar's test depends only on cases classified in different categories (that is, the discordant cells) for the two matched observations, but all cases contribute to inferences about how much $\pi_{1+}$ and $\pi_{+1}$ differ. It is thus equivalent to a fixed effects logit model with only the treatment effect as a predictor. The test statistic simplifies to:

$$
\chi_{1}^{2}=\frac{n_{21}-n_{12}}{\sqrt{n_{21}+n_{12}}}
$$

For paired designs with dichotomous outcomes, statistical power depends on more than the magnitude difference in treatment and control acceptance rates (Vuolo et al., 2016). First, the proportion of pairs in the concordant cells (i.e., neither or both testers were accepted) compared to the discordant cells (i.e., the testers received different outcomes) contributes to the power. Second, power is lower as the discordant proportions simultaneously approach 0.5 . Although these quantities are difficult to determine a priori, we computed power and sample size following the recommendations and R functions in Vuolo et al. (2016) in the design phase. Balancing these estimates against the average anticipated cost of each application, our study design should be sufficient to detect a 5 to 10 percentage point difference between treatment and control groups.

For multivariate analysis, we use the random effects logit model, or generalized linear mixed model (GLMM), due to our interest in effects that vary between colleges (e.g., selectivity, cost) and the heterogeneity between colleges. For a dichotomous outcome in a block design (Agresti, 2013, p. 491), this model is represented by the following equations: 


$$
\operatorname{logit}\left[P\left(Y_{i 1}=1 \mid u_{i}\right)\right]=\alpha+u_{i} \quad \operatorname{logit}\left[P\left(Y_{i 2}=1 \mid u_{i}\right)\right]=\alpha+\beta+u_{i}
$$

where $u_{i}=\alpha_{i}-\alpha$ for some constant $\alpha$. Here, $u_{i}$ is a random effect for employer cluster $i$, with $\left\{u_{i}\right\}$ independent from a normal distribution with mean 0 and variance $\sigma^{2}$ with $\sigma$ unknown. Because the univariate random effect adjusts the intercept but does not modify the fixed effect, the model is often called a random intercept model. Instead of the usual fixed intercept $\alpha$, it has a random intercept $\alpha+u_{i}$. The fixed effects, or betas, are typically the main focus of a GLMM, with the random effects describing positive correlation between observations within a cluster. The random effects parameters also indicate the degree of heterogeneity of a population.

Note that the fixed effects represent cluster-specific rather than population-average effects. That is, $\beta$ is the effect of an arrest record on the probability that a given college will accept one applicant relative to the other applicant. The first equation is thus the probability that a particular college will accept the tester with no record; the second is the probability the same college will accept the tester reporting a felony record. A predictor that does not vary within a college, such as the race of the two testers submitting applications, can be interpreted as the effect for those with a similar random effect for the different groups (e.g., racial categories) (Agresti, 2013, p. 495). GLMM models were estimated with the melogit procedure in Stata 14.1 (StataCorp, College Station, TX), and we calculated predicted values as average marginal effects (Muller \& MacLehose, 2014). To check model robustness, we used a bootstrapped approach by resampling from the 280 paired tests across 10,000 replications. The bootstrapped standard errors changed slightly but were consistent with the standard errors presented below. 


\section{RESULTS}

In Figure 1, we show the proportion of applicant profiles rejected by race and felony record status. Tester applicant profiles with felony records (that is, "Record testers") were rejected roughly 2.5 times more than their counterparts without felony records (that is, "No Record testers") across both race conditions. White No Record testers had the lowest rejection rate (9.2 percent) followed by Black No Record testers (10.7 percent). The rejection rates for the Record testers were significantly higher, 23.8 percent when applying as White and 26.7 percent when applying as Black, for differences of 14.6 and 16 percentage points, respectively (both differences were significant in a two-sample $t$-test at $p<.001$ ). Black applicants in both record conditions were rejected at slightly higher rates (1.5 percentage points higher for those without

felony records and 2.9 percentage points higher for those with records), although a two-sample $t$ test of the difference by race between the Black and White applicants with records is not statistically significant.

[Figure 1 about here.]

\section{BIVARIATE AUDIT ANALYSIS}

As noted, McNemar (1947) provides a test of whether the proportional differences in rejection rates between No Record testers and Record testers are significant. For this analysis, each college is treated as a single experimental unit, or a case, and placed in one of the four cells of a $2 \times 2$ contingency table. As reported in the first panel of Table 3, when our testers applied as Black, both were accepted by 67.3 percent of colleges and both were rejected by 4.7 percent of 
colleges. In the discordant cells, 6 percent of colleges rejected the No Record tester but accepted the Record tester, while 22 percent accepted the No Record tester but rejected the Record tester. A McNemar's two-tailed test of the discordant cells, which checks for consistency across two variables, is statistically significant at the $p<.001$ level with an odds-ratio (interpreted as "only No Record tester accepted to only Record tester accepted") of 3.667.

When our testers applied as White (second panel of Table 3), we find a similar and somewhat stronger pattern. Both White testers were accepted by 73.8 percent of colleges (slightly higher than our Black applicants), and both were rejected by 6.9 percent of colleges. On the off-diagonal, the No Record tester was rejected and the Record tester was accepted by 2.3 percent of colleges while the opposite scenario - No Record tester accepted; Record tester rejected-occurred at 16.9 percent of colleges. A two-tailed McNemar's test is again significant at the $p<.001$ level with an odds-ratio of 7.333. Although it may seem that a felony record has a stronger negative impact for White applicants, we caution against this interpretation (and return to this issue in the mixed effects models below). The odds ratio is a comparison of "only the No Record tester accepted to only the Record tester accepted," which is dependent on the proportions in the off-diagonal cells. Here, the lower odds-ratio for our Black sample results from the combination of the slightly lower overall acceptance rates (as seen in Figure 1) and higher variability in outcomes when our testers applied as Black (compare $p_{10}$ and $p_{01}$ of the Black panel to the White panel in Table 3).

[Table 3 about here.] 
Although this study's paired design is best understood as consisting of two separate experiments by race, pooling the two samples can be informative for the present study and future research. We present the pooled results in the third panel of Table 3. When pooled, both testers were accepted at 70.4 percent of colleges, both were rejected at 5.7 percent, the No Record tester was rejected and the Record tester was accepted at 4.3 percent, and the No Record tester was accepted and the Record tester was rejected at 19.6 percent. As with the Black and White results separately, a two-tailed McNemar's test of the pooled results is significant at the $p<.001$ level with an odds-ratio of 4.583. To summarize the bivariate results, a felony record is not a categorical disqualifier in the higher education context, but having a felony record leads to significantly higher rejection rates for both Black and White applicants.

\section{LOGISTIC MIXED EFFECTS REGRESSION MODELS}

We next present logistic mixed-effects models predicting college acceptance, shown in Table 4 for the Black sample (models 1-3), the White sample (models 4-6), and the pooled sample (models 7-10). As previously note, we used a bootstrapped approach by resampling from the 280 completed pairs across 10,000 replications for each model, and the resulting biascorrected standard errors were consistent with those presented in Table 4. For each, we present models with and without covariates. Models 1 and 4 are race-specific and include only the fixed effect of the felony record and a random effect for college. As with the bivariate results in Table 3 , we find strong felony record effects for both race groups, though the felony record coefficient is larger for the White tester sample (-1.97 versus -1.30). A comparison of the intercepts shows a greater probability of acceptance when our testers, all of whom surpassed the minimum 
admissions standards of the college, applied as White than when they apply as Black, which likely explains in part the larger felony record coefficient.

[Table 4 about here.]

The addition of covariates in models 2 and 5 potentially moderates the influence of confounding variables not accounted for in the sampling process, adjusting for college characteristics and audit design characteristics. The added covariates reduce the random effect variance, indicating that a substantial proportion of the college-level variance can be explained by institutional characteristics. The main effect of the felony record is robust for both samples and again is a bit larger for the White applicants $(-2.02 ; p<.01$, two-tailed) compared to the Black applicants $(-1.35 ; p<.001$, two-tailed). Additionally, controlling for other covariates (including whether the tester had a felony record), the presence of a criminal history disclosure question was negatively associated with acceptance for both samples, though the relationship was marginally significant for the White applicants $(-1.74 ; p<0.1$, two-tailed) compared to Black applicants (-1.38; $p<.01$, two-tailed). For our Black applicants, acceptance was more likely at colleges with larger proportions of undergraduates who were White or who were receiving Pell Grants.

College administrators often support apprehension about admitting applicants with criminal records due to concerns about campus crime and public safety - or the perception of campus safety (Pierce et al., 2014). In models 3 and 6, we add an interaction term to test whether applicants with felony records fare worse at colleges with higher perceived crime rates, using 10 
or more reported incidents of crime per 1,000 students according to Clery Act data in the previous three years as a rough indicator of high crime rate. Indeed, on campuses that report more crime, Black record applicants were significantly less likely $(p<.05$, two-tailed) to be accepted compared to Black no-record applicants. We observed a similar though non-significant pattern for White felon applicants. Under this coding, the main effect of felony record (indicating its effect on campuses with lower crime rates) is significant and negative in model $6(-1.46, p<$ .05 , for White applicants) but not model 3 (for Black applicants).

We pool our two race-specific samples and present the logistic mixed effects estimates models 7-10 in Table 4. Although we did not include cross-race pairs (that is, one Black and one White applicant within a pair) applying to the same colleges in our design, the same pairs of applicants with the same academic credentials and records applied to the colleges of both samples but varied their race. Estimates for models that include only a fixed effect for felony record and a random effect for college are presented in model 7, and a fixed effect for Black race is added in model 8 . In both models, felony record is negative and statistically significant ( $p<$ .001 , two-tailed). The non-significant race effect suggests that differences between Black and White applicants are not distinguishable from zero, net of the felony record condition. Results for pooled models with covariates (in model 9) and the felony record/high crime rate interaction (in model 10) generally parallel the race-specific models.

The effects under the interaction coding in model 10 indicate that a felony record becomes a moderate hurdle for applicants at colleges with low crime rates but a bigger hurdle at colleges with high crime rates overall. To elaborate and clarify these results, Figure 2 presents predicted probabilities of admission by race, record, and college crime rate. We find that 
applicants without records fared well regardless of race and the local college crime rate, with acceptance probabilities of at least $86 \%$. This probability declines to $76.6 \%$ for Black testers and $80.4 \%$ for White testers with records in low-crime contexts. In higher-crime contexts, the marginal probability of admission drops to $68.2 \%$ for Black applicants with records and $72.8 \%$ for White applicants with records. In short, Black applicants with felony records applying to colleges with higher crime rates face the greatest likelihood of rejection.

[Figure 2 about here.]

\section{IMPACT OF CRIMINAL HISTORY DISCLOSURE QUESTIONS}

Evaluations of recent "ban the box" (BTB) initiatives that restrict criminal history questions on employment applications have identified potential adverse effects on Black men without records (Agan and Starr, 2018; Vuolo et al., 2017). Our analysis may provide some initial reassurance that such adverse outcomes are less likely in the higher education context. Because our design included both colleges that required criminal history information and colleges that did not, we are able to directly compare how our Record and No Record testers fared under each condition. We did not sample on whether a college required criminal history disclosure, so we caution readers that this comparison is not perfectly interpretable and should be understood as exploratory. Nevertheless, we show in Figure 3 the rejection rates of applicants with records and without records from the pooled sample at colleges with "the box" and colleges without "the box." When required to disclose their felonies, the Record testers were rejected by a 
full third of colleges in the sample. But when they were not required to disclose their felonies, their rejection rate dropped precipitously to only five percent, while the No Record testers fared slightly worse at colleges without the box (11.4 percent rejected without the box, compared to 9.5 percent with the box) This low rate of rejection for the Record testers is to be expected, as our design ensured that the testers presenting records should have been somewhat more attractive to admissions officials than the No Record testers.

[Figure 3 here.]

Based on these results, we next explored whether Black applicants without records were harmed by removal of criminal history information from college applications in Figure 4. We again estimate marginal probabilities of acceptance, though we depart from our paired design to include all complete No Record testers $(\mathrm{n}=330)$ using a logit equation that interacts race and $\mathrm{CHQ}$ with the same controls from Figure 4 constant at their means. We find that differences within race in the probability of acceptance for colleges with and without the box are not statistically significant. The difference between college categories is indeed larger for Black applicants who saw a decrease in acceptance of 5.8 percentage at colleges that do not ask compared to an increase of nearly 1.8 percentage points for White applicants, though these differences were not statistically different from each other. Although we again caution that we did not sample on whether colleges required criminal history information, we did not find strong evidence suggesting that Ban the Box in higher education admissions would have a pronounced adverse effect on outcomes for Black males. 
[Figure 4 here.]

\section{DISCUSSION AND LIMITATIONS}

This study posed three basic questions regarding criminal records and college admissions, which we discuss in turn. First, we find that four-year colleges clearly discriminate on the basis of criminal records. By comparing rejection rates of college applicants with and without criminal records, we find that applicants with prior criminal records were rejected at a rate approximately 3 times higher than applicants without records from colleges that require criminal history information. Moreover, due to asymmetric matching, our results are conservative by design. Had we instead included testers with equally or matched educational credentials, it is likely the impact of the felony record would be larger. Similarly, we would also expect a greater impact for individuals presenting more extensive or more serious criminal histories than the single low-level simple robbery and burglary felonies presented by our testers. These results should thus be interpreted as a baseline measure of discrimination against college applicants with criminal records. ${ }^{5}$

\footnotetext{
${ }^{5}$ We are not aware of reliable data on the number of college applicants each year with criminal records, thus making precise baseline estimates of how many applicants might be denied because of their records difficult. Nevertheless, based on the prevalence of affirmative criminal history responses on SUNY system applications (Rosenthal et al., 2015), arrests and misdemeanor convictions among young people (Brame et al., 2014; Hepburn, Kohler-Hausmann, \& Zorro Medina, 2019), and felony convictions nationally (Shannon et al., 2017), we estimate that at least $1.5 \%$ (or
} 
There are several reasons for caution in generalizing our findings. Because we left the field with 280 completed pairs from our original sample of 400 , these results yield a local average treatment effect. These findings are further limited because they cannot speak to all possible combinations of criminal record type/severity, academic background, gender, and race/ethnicity. We made the design choice to exclude the top two competitiveness tiers out of concern that our testers would not be competitive since all of our testers' ACT composite scores were below the $25^{\text {th }}$ percentile for those top tiers. The field would benefit from future research that explores these combinations, particularly different criminal record types (e.g., drug, violent, sex offenses), severities, gender differences at different levels of admissions selectivity and academic qualifications.

Although most of our applications were ultimately accepted in both the record and norecord conditions, we note that it was far more difficult to complete applications that requested criminal history information. Higher rejection rates are thus not the only effects of these questions. Work by the Center for Community Alternatives (Weissman et al., 2010; Rosenthal et al., 2015) has suggested that CHQs on college applications have a chilling effect on applicants with criminal records. CCA analyzed data from nearly half of the institutions in the SUNY system and found that the median attrition rate, or rate at which applicants start but do not finish an application, is almost 3 times higher for applicants who disclose a criminal record than for the general population. Our experience attempting to comply with the requirements asked of our

$102,000)$ of the 6.8 million applications submitted to four-year colleges that required criminal history information would have reported a criminal conviction in 2016. Applying our findings from Figure 2 for colleges that require criminal history information, we estimate that at least 25,000 applicants were denied in 2016. 
felony-record applicants confirms this finding: it is fatiguing and frustrating to compile and report all the documentation, information, and one-to-one correspondence required of applicants with records. CCA also compared the attrition rate to the rejection rate for applicants with criminal records and found that for every applicant rejected, there were fifteen applicants who dropped out of the application process and did not complete their applications. Although there is no way to assess the extent to which these questions might deter potential applicants with records, the deterrent effect is likely substantial. Although we were diligent in completing the requirements that were feasible within the confines of our field experiment, it is entirely likely that we went far above and beyond what a typical applicant may have been willing to complete. Further examination of the admissions process from the perspective of applicants, including how these questions are interpreted and how the process is navigated, would provide insight into how these questions and associated processes may be indirectly exclusionary.

Our second research question asks whether discrimination on the basis of criminal records varied by race and institutional context. Relative to the large race gaps observed in studies of employment discrimination (Pager, 2007a; Uggen et al., 2014), we find smaller race differences in college admissions. In general, educational institutions responded in similar ways to our applicants, regardless of whether they self-identified as Black or White on their applications. However, it is impossible to know whether our race signal - checking a box on the application - was itself a strong or salient enough signal, or whether colleges admissions officers were privy to race information. Although we did include whether a college considers race in admissions drawn from responses to The College Board's Annual Survey of Colleges, we do not know how they consider race, particularly at non-elite colleges (kehal, Hirschman, and Berrey, 2018). 
Nevertheless, we did observe racial differences when examining the interaction of criminal records with college crime rates. As we had expected, colleges with higher levels of reported crime were more cautious, but particularly when reviewing applications from Black males with records, who had the lowest probability of acceptance at higher crime colleges and the largest differential when compared to their counterparts without criminal records. Here, race interacts with institutional context, in the form of campus crime issues, to affect how applicants with records are appraised, and Black applicants. More pronounced race signals and additional institutional settings could provide important insights into how racial identification and perceptions of campus crime operate within the higher education context.

Finally, we considered the likely impact of a Ban-the-Box strategy to remove criminal records questions from college application forms. Post-BTB analyses of employment suggest that the policy may have unintended consequences, particularly for Black male applicants without criminal records (Agan and Starr, 2018). Our findings indicate that banning the box on college applications would be less likely to produce such large detrimental impacts. Relative to employment audits, we find far less overall racial discrimination in college admissions decisions and relatively small and non-significant differences in the appraisal of Black applicants without criminal records in the presence or absence of these questions. We would suggest, however, that any BTB policy - particularly reforms that would delay asking to a later point in the process must be accompanied by vigilance and monitoring to ensure that prohibitions on racial discrimination are strictly enforced. Future research could pursue an alternative design that directly addresses the potential impact of BTB by sampling on the criminal history disclosure question. We offer further advice on the modified audit approach in Appendix 2. 
There are, of course, other strategies that are commonly discussed when focusing on the harms of criminal record stigma, including record expungement, sealing, and other similar remedies. We do not, however, emphasize these strategies in the present study because they often require a waiting period of five or more years after the end of the sentence before an applicant is eligible to apply. Thus, applicants would have to put off college for a considerable amount of time, often until their late 20 s or later, before they could take advantage of these mechanisms. We also do not engage expungements and similar approaches because of their low uptake (see, e.g., Prescott and Starr [2019] who found that only a fraction of people eligible for expungements in Michigan pursued them), the typically narrow scope of eligible criminal histories, and the lack of an organized movement centered around record sealing and college admissibility. We therefore note these as potential remedies but focus more explicitly on the currently popular approaches to removing criminal records questions from admissions. Our study and design are best suited to address the impact of BTB, although subsequent research with an older sample of sealed or expunged testers certainly seems merited.

\section{CONCLUSION}

Our results expose a significant aftereffect of criminal justice involvement. Education has classically been viewed as a pathway to escape poverty and enhance social mobility, but it cannot fulfill this function if institutions systematically disqualify applicants disproportionately drawn from communities of color. Although the race differences observed in the educational setting are less pronounced compared to previous audits of employers, we note that the level of applicants with records is far greater among Blacks, even if the effects of these records are roughly proportional to those for Whites. 
Further, this study extends prior work on the stigma of criminal records, testing whether it limits educational opportunities as it does in many other areas of life (Pager, 2003; Uggen and Stewart, 2014). Despite high overall acceptance rates for the qualified applicants in our study, we nevertheless observe significant discrimination in higher education admissions. The path toward a post-secondary degree is thus much rockier for the 19 million Americans with felony-level criminal records, a disproportionate proportion of which are young Black men (Shannon et al., 2017).

These findings also address fundamental questions in the sociologies of education and knowledge, providing new evidence and insight regarding the role, duty, and accessibility of higher education institutions. Many colleges claim a commitment to diversity to foster a rich learning environment for students and wide-ranging perspectives in the production of knowledge. By revealing how certain groups are excluded, this research speaks to the limits of the growth and development of knowledge when segments of the population are barred from participating (Uggen, Horowitz, \& Stewart, 2017). More broadly, such efforts facilitate understanding of the role of criminal justice institutions in educational attainment.

Finally, this research yields important and actionable information for policy makers and the public. Although more research is clearly needed to explicate the basic findings presented here, we now have clear evidence that colleges that inquire about criminal histories are using them to screen out applicants with records. And, perhaps unsurprisingly, those that do not inquire about this information do not discriminate on the basis of criminal records. For the 70 percent of colleges that request criminal history information on their application forms, it is timely and important that they consider narrowing the scope of such inquiries or removing the question altogether - particularly when it conflicts with other stated goals of these institutions, including 
reducing the underrepresentation of men and women of color on campus. Apart from such "upstream" changes in policy, these findings also direct attention "downstream" toward improving the competitiveness of applicants with records - identifying reentry and reintegration strategies to better prepare people with records for the application process. Ultimately, we hope this study can play some small part in facilitating the needed science and policy conversations on the stigmatizing effect of criminal records in higher education. 


\section{REFERENCES}

Agan, A., \& Starr, S. (2017). The Effect of Criminal Records on Access to Employment. American Economic Review, 107(5), 560-564. https://doi.org/10.1257/aer.p20171003

Agan, A., \& Starr, S. (2018). Ban the Box, Criminal Records, and Racial Discrimination: A Field Experiment. The Quarterly Journal of Economics, 133(1), 191-235. https://doi.org/10.1093/qje/qjx028

Agresti, A. (2013). Categorical Data Analysis (3rd ed.). Hoboken, NJ: John Wiley \& Sons, Incorporated.

Ahmed, A. M., \& Lång, E. (2017). The employability of ex-offenders: a field experiment in the Swedish labor market. IZA Journal of Labor Policy, 6(1), 6. https://doi.org/10.1186/s40173-017-0084-2

Alon, S., \& Tienda, M. (2005). Assessing the "mismatch" hypothesis: Differences in college graduation rates by institutional selectivity. Sociology of Education, 78(4), 294-315.

Arum, R., \& Hout, M. (1998). The early returns: The transition from school to work in the United States. In Y. Shavit \& W. Muller (Eds.), From school to work: A comparative study of educational qualifications and occupational destinations (pp. 471-510). New York: Clarendon Press.

Avery, B., \& Hernandez, P. (2018, February 8). Ban the Box: U.S. Cities, Counties, and States Adopt Fair Hiring Policies. Retrieved April 14, 2018, from National Employment Law Project website: http://www.nelp.org/publication/ban-the-box-fair-chance-hiring-stateand-local-guide/

Ayres, I., \& Siegelman, P. (1995). Race and gender discrimination in bargaining for a new car. The American Economic Review, 85, 304-321.

Baert, S., \& Verhofstadt, E. (2015). Labour market discrimination against former juvenile delinquents: evidence from a field experiment. Applied Economics, 47(11), 1061-1072. https://doi.org/10.1080/00036846.2014.990620

Barron's College Division Staff. (2015). Barron's Profiles of American Colleges, 2016 (32nd ed.). Hauppauge, NY: Barrons Educational Series, Inc.

Becker, G. S. (1994). Human Capital: A Theoretical and Empirical Analysis, with Special Reference to Education (3rd ed.). Chicago, IL: The University of Chicago Press.

Berg, M. T., \& Huebner, B. M. (2011). Reentry and the ties that bind: An examination of social ties, employment, and recidivism. Justice Quarterly, 28(2), 382-410.

Bertrand, M., \& Mullainathan, S. (2004). Are Emily and Greg more employable than Lakisha and Jamal? A field experiment on labor market discrimination. The American Economic Review, 94(4), 991-1013.

Blomberg, T. G., \& Pesta, G. B. (2017). Education and Delinquency. In C. J. Schreck (Ed.), The Encyclopedia of Juvenile Delinquency and Justice. Retrieved from https://onlinelibrary.wiley.com/doi/abs/10.1002/9781118524275.ejdj0044 
Boli, J., Ramirez, F. O., \& Meyer, J. W. (1985). Explaining the origins and expansion of mass education. Comparative Education Review, 29(2), 145-170.

Bowen, W. G., \& Bok, D. (2016). The shape of the river: Long-term consequences of considering race in college and university admissions. Princeton University Press.

Brame, R., Bushway, S. D., Paternoster, R., \& Turner, M. G. (2014). Demographic patterns of cumulative arrest prevalence by ages 18 and 23. Crime \& Delinquency, 60(3), 471-486.

Brown, D. K. (2001). The social sources of educational credentialism: Status cultures, labor markets, and organizations. Sociology of Education, 74, 19-34.

Carini, R. M., Hayek, J. C., Kuh, G. D., Kennedy, J. M., \& Ouimet, J. A. (2003). College student responses to web and paper surveys: Does mode matter? Research in Higher Education, 44(1), 1-19.

Carnevale, A. P., Rose, S. J., \& Cheah, B. (2013). The college payoff: Education, occupations, lifetime earnings. Retrieved from Georgetown University Center on Education and the Workforce website:

https://repository.library.georgetown.edu/bitstream/handle/10822/559300/collegepayoffcomplete.pdf? sequence $=1$

Children's Bureau. (2015). Background Checks for Prospective Foster, Adoptive, and Kinship Caregivers. Retrieved from https://www.childwelfare.gov/pubPDFs/background.pdf

Cox, D. R. (1958). Planning of experiments. Oxford: Wiley.

Custer, B. D. (2018). Applying to university with criminal convictions: a comparative study of admissions policies in the United States and United Kingdom. Journal of Higher Education Policy and Management, $0(0), 1-17$. https://doi.org/10.1080/1360080X.2018.1462436

Davis, L. M., Bozick, R., Steele, J. L., Saunders, J., \& Miles, J. N. (2013). Evaluating the effectiveness of correctional education: A meta-analysis of programs that provide education to incarcerated adults. Rand Corporation.

Decker, S. H., Ortiz, N., Spohn, C., \& Hedberg, E. (2015). Criminal stigma, race, and ethnicity: The consequences of imprisonment for employment. Journal of Criminal Justice, 43(2), 108-121.

Denver, M., Siwach, G., \& Bushway, S. D. (2017). A New Look at the Employment and Recidivism Relationship Through the Lens of a Criminal Background Check*. Criminology, 55(1), 174-204. https://doi.org/10.1111/1745-9125.12130

Dickerson, D. (2008). Background Checks in the University Admissions Process: An Overview of Legal and Policy Considerations. Journal of College and University Law, 34, 419-506.

Doleac, J. L., \& Hansen, B. (2016). Does "ban the box” help or hurt low-skilled workers? Statistical discrimination and employment outcomes when criminal histories are hidden. National Bureau of Economic Research.

Dresser, M. (2018, January 12). Maryland Senate overrides Hogan veto of bill barring college admissions from asking about arrests. The Baltimore Sun. Retrieved from 
http://www.baltimoresun.com/news/maryland/politics/bs-md-college-admissions20180112-story.html

Duwe, G., \& Clark, V. (2014). The effects of prison-based educational programming on recidivism and employment. The Prison Journal, 94(4), 454-478.

Evans, D. N. (2016). The effect of criminal convictions on real estate agent decisions in New York City. Journal of Crime and Justice, 39(3), 363-379. https://doi.org/10.1080/0735648X.2016.1166068

Evans, D. N. (2019). Full disclosure: experimental analysis of female online dating on parole. Journal of Experimental Criminology. https://doi.org/10.1007/s11292-019-09357-2

Evans, D. N., \& Porter, J. R. (2015). Criminal history and landlord rental decisions: a New York quasi-experimental study. Journal of Experimental Criminology, 11(1), 21-42. https://doi.org/10.1007/s11292-014-9217-4

Fisher, B. S., Hartman, J. L., Cullen, F. T., \& Turner, M. G. (2002). Making campuses safer for students: The Clery Act as a symbolic legal reform. Stetson L. Rev., 32, 61.

Ford, J. A., \& Schroeder, R. D. (2010). Higher education and criminal offending over the life course. Sociological Spectrum, 31(1), 32-58.

Furst, R. T., \& Evans, D. N. (2017). Renting Apartments to Felons: Variations in Real Estate Agent Decisions due to Stigma. Deviant Behavior, 38(6), 698-708. https://doi.org/10.1080/01639625.2016.1197635

Gaddis, S. M. (2015). Discrimination in the credential society: an audit study of race and college selectivity in the labor market. Social Forces, 93(4), 1451-1479.

Gaddis, S. M. (2017). How Black Are Lakisha and Jamal? Racial Perceptions from Names Used in Correspondence Audit Studies. Sociological Science, 4, 469-489. https://doi.org/10.15195/v4.a19

Gaddis, S. M. (2018a). An introduction to audit studies in the social sciences. In S. M. Gaddis (Ed.), Audit Studies: Behind the Scenes with Theory, Method, and Nuance (pp. 3-44). Springer International Publishing.

Gaddis, S. M. (Ed.). (2018b). Audit Studies: Behind the Scenes with Theory, Method, and Nuance. Springer International Publishing.

Galgano, S. W. (2009). Barriers to Reintegration: An Audit Study of the Impact of Race and Offender Status on Employment Opportunities for Women. Social Thought \& Research, 30, 21-37. Retrieved from JSTOR.

Ghoshal, R., \& Gaddis, S. M. (2015). Finding a Roommate on Craigslist: Racial Discrimination and Residential Segregation. Social Science Research Network. Retrieved from https://papers.ssrn.com/sol3/papers.cfm?abstract_id=2605853

Gustafson, K. S. (2011). Cheating welfare: Public assistance and the criminalization of poverty. NYU Press.

Hart, T. C. (2007). Violent victimization of college students: Findings from the National Crime Victimization Survey. Campus Crime: Legal, Social, and Policy Perspectives, 129-146. 
Heckman, J. J. (1998). Detecting discrimination. The Journal of Economic Perspectives, 12(2), 101-116.

Hepburn, P., Kohler-Hausmann, I., \& Zorro Medina, A. (2019). Cumulative Risks of Multiple Criminal Justice Outcomes in New York City. Demography. https://doi.org/10.1007/s13524-019-00781-7

Hirschman, D., \& Berrey, E. (2017). The Partial Deinstitutionalization of Affirmative Action in U.S. Higher Education, 1988 to 2014. Sociological Science, 4, 449-468. https://doi.org/10.15195/v4.a18

Hughes, S. F., Elliott, T. L., \& Myers, M. (2014). Measuring the Impact of Student Background Checks on Reducing Crime in Higher Education. Public Administration Research, 3(2), 121. https://doi.org/10.5539/par.v3n2p121

Jaschik, S. (2016, September 15). SUNY Bans the Box. Retrieved October 23, 2017, from Inside Higher Ed website: https://www.insidehighered.com/news/2016/09/15/suny-removesquestion-criminal-convictions-application

Kaeble, D., \& Glaze, L. E. (2016). Correctional Populations In The United States, 2015 (No. NCJ 250374). Retrieved from Bureau of Justice Statistics website: https://www.bjs.gov/index.cfm?ty=pbdetail\&iid $=5870$

kehal, p.s., Hirschman, D., \& Berrey, E. (2018, August). Trends in Affirmative Action Admissions Policies and Student Enrollment at Selective Colleges, 1990-2016. Presented at the Annual Meeting of the American Sociological Association, Philadelphia, PA.

Kim, R. H., \& Clark, D. (2013). The effect of prison-based college education programs on recidivism: Propensity Score Matching approach. Journal of Criminal Justice, 41(3), 196-204. https://doi.org/10.1016/j.jcrimjus.2013.03.001

Klasik, D. (2012). The college application gauntlet: A systematic analysis of the steps to fouryear college enrollment. Research in Higher Education, 53(5), 506-549.

Kurlychek, M. C., Brame, R., \& Bushway, S. D. (2006). Scarlet letters and recidivism: Does an old criminal record predict future offending? Criminology \& Public Policy, 5(3), 483504.

Lageson, S. E., Vuolo, M., \& Uggen, C. (2015). Legal ambiguity in managerial assessments of criminal records. Law \& Social Inquiry, 40(1), 175-204.

Lahey, J., \& Beasley, R. (2018). Technical aspects of correspondence studies. In S. M. Gaddis (Ed.), Audit Studies: Behind the Scenes with Theory, Method, and Nuance (pp. 81-101). Springer International Publishing.

Laub, J. H., \& Sampson, R. J. (2001). Understanding desistance from crime. Crime and Justice, $28,1-69$.

Lockwood, S., Nally, J. M., Ho, T., \& Knutson, K. (2012). The Effect of Correctional Education on Postrelease Employment and Recidivism: A 5-Year Follow-Up Study in the State of Indiana. Crime \& Delinquency, 58(3), 380-396. https://doi.org/10.1177/0011128712441695 
Lovenheim, M. F., \& Owens, E. G. (2014). Does federal financial aid affect college enrollment? Evidence from drug offenders and the Higher Education Act of 1998. Journal of Urban Economics, 81, 1-13. https://doi.org/10.1016/j.jue.2014.01.005

Manza, J., \& Uggen, C. (2006). Locked out: Felon disenfranchisement and American democracy. Retrieved from https://books.google.com/books?hl=en\&lr=\&id=BxkTDAAAQBAJ\&oi=fnd\&pg=PR15 $\& d q=u g g e n+d i s e n f r a n c h i s e m e n t \& o t s=d 7 h x e \_T B R j \& s i g=u l t R Z d u O 860 N 0 i o 2 z-$ ZceIFseGo

Massoglia, M., Remster, B., \& King, R. D. (2011). Stigma or Separation? Understanding the Incarceration-Divorce Relationship. Social Forces, 90(1), 133-155. https://doi.org/10.1093/sf/90.1.133

May, B. E. (1995). The character component of occupational licensing laws: A continuing barrier to the ex-felon's employment opportunities. NDL Rev., 71, 187.

Mayhew, M. J., Bowman, N. A., Rockenbach, A. N., Seifert, T. A., \& Wolniak, G. C. (2016). How college affects students: 21 st century evidence that higher education works (Vol. 3). John Wiley \& Sons.

McNemar, Q. (1947). Note on the sampling error of the difference between correlated proportions or percentages. Psychometrika, 12(2), 153-157.

Monks, J. (2000). The returns to individual and college characteristics: Evidence from the National Longitudinal Survey of Youth. Economics of Education Review, 19(3), 279289.

Muller, C. J., \& MacLehose, R. F. (2014). Estimating predicted probabilities from logistic regression: different methods correspond to different target populations. International Journal of Epidemiology, 43(3), 962-970. https://doi.org/10.1093/ije/dyu029

Neumark, D. (2018). Experimental research on labor market discrimination. Journal of Economic Literature, 56(3), 799-866.

Neumark, D., Bank, R. J., \& Van Nort, K. D. (1996). Sex discrimination in restaurant hiring: An audit study. The Quarterly Journal of Economics, 111(3), 915-941.

Newhouse, R. (2017, October 5). Louisiana Limits Public Colleges and Universities from Asking Applications About Criminal History. Retrieved October 23, 2017, from Teen Vogue website: https://www.teenvogue.com/story/louisiana-limits-public-colleges-anduniversities-from-asking-applications-about-criminal-history

Olszewska, M. J. (2007). Undergraduate admission application as a campus crime mitigation measure: Disclosure of applicants' disciplinary background information and its relation to campus crime. East Carolina University.

Pager, D. (2003). The mark of a criminal record. American Journal of Sociology, 108(5), 937975.

Pager, D. (2007a). Marked: Race, crime, and finding work in an era of mass incarceration. Retrieved from https://books.google.com/books?hl=en\&lr=\&id=f067Pjis- 
T0C\&oi=fnd \&pg=PR5\&dq=devah+pager\&ots=krmCvSnba9\&sig=8wnZogGd89GsGvkv K2FsnXFCHiQ

Pager, D. (2007b). The use of field experiments for studies of employment discrimination: Contributions, critiques, and directions for the future. The Annals of the American Academy of Political and Social Science, 609(1), 104-133.

Pager, D., Bonikowski, B., \& Western, B. (2009). Discrimination in a low-wage labor market: A field experiment. American Sociological Review, 74(5), 777-799.

Pager, D., Western, B., \& Sugie, N. (2009). Sequencing disadvantage: Barriers to employment facing young black and white men with criminal records. The ANNALS of the American Academy of Political and Social Science, 623(1), 195-213.

Phelps, E. S. (1972). The statistical theory of racism and sexism. The American Economic Review, 62(4), 659-661.

Phillips, D. C. (n.d.). Do Comparisons of Fictional Applicants Measure Discrimination When Search Externalities Are Present? Evidence from Existing Experiments. The Economic Journal, O(ja). https://doi.org/10.1111/ecoj.12628

Pierce, M. W., Runyan, C. W., \& Bangdiwala, S. I. (2014). The use of criminal history information in college admissions decisions. Journal of School Violence, 13(4), 359-376.

Prescott, J. J., \& Starr, S. B. (2019). Expungement of Criminal Convictions: An Empirical Study (SSRN Scholarly Paper No. ID 3353620). Retrieved from Social Science Research Network website: https://papers.ssrn.com/abstract=3353620

Ramaswany, R. R. (2014). Bars to Education: The Use of Criminal History Information in College Admissions. Columbia Journal of Race and Law, 5, 145-164.

Ridley, S., Bayton, J. A., \& Outtz, J. H. (1989). 'Taxi Service in the District of Columbia: Is it Influenced by Patron's Race and Destination?'”. Washington, DC Lawyer's Committee for Civil Rights Under the Law.

Roderick, M., Coca, V., \& Nagaoka, J. (2011). Potholes on the road to college: High school effects in shaping urban students' participation in college application, four-year college enrollment, and college match. Sociology of Education, 84(3), 178-211.

Rosenthal, A., NaPier, E., Warth, P., \& Weissman, M. (2015). Boxed Out: Criminal History Screening and College Application Attrition. Retrieved from Center for Community Alternatives website:

http://www.communityalternatives.org/pdf/publications/BoxedOut_FullReport.pdf

Runell, L. L. (2017). Identifying Desistance Pathways in a Higher Education Program for Formerly Incarcerated Individuals. International Journal of Offender Therapy and Comparative Criminology, 61(8), 894-918. https://doi.org/10.1177/0306624X15608374

Runyan, C. W., Pierce, M. W., Shankar, V., \& Bangdiwala, S. I. (2013). Can student-perpetrated college crime be predicted based on precollege misconduct? Injury Prevention, 19(6), 405-411. 
Sauder, M., \& Lancaster, R. (2006). Do Rankings Matter? The Effects of U.S. News \& World Report Rankings on the Admissions Process of Law Schools. Law \& Society Review, 40(1), 105-134. https://doi.org/10.1111/j.1540-5893.2006.00261.x

Schulman, K. A., Berlin, J. A., Harless, W., Kerner, J. F., Sistrunk, S., Gersh, B. J., ... others. (1999). The effect of race and sex on physicians' recommendations for cardiac catheterization. New England Journal of Medicine, 340(8), 618-626.

Schwartz, R. D., \& Skolnick, J. H. (1962). Two studies of legal stigma. Social Problems, 10(2), $133-142$.

Shannon, S. K., Uggen, C., Schnittker, J., Thompson, M., Wakefield, S., \& Massoglia, M. (2017). The Growth, Scope, and Spatial Distribution of People With Felony Records in the United States, 1948-2010. Demography, 1-24.

Skardhamar, T., \& Savolainen, J. (2014). Changes in Criminal Offending Around the Time of Job Entry: A Study of Employment and Desistance. Criminology, 52(2), 263-291. https://doi.org/10.1111/1745-9125.12037

Sloan III, J. J., Fisher, B. S., \& Cullen, F. T. (1997). Assessing the student right-to-know and Campus Security Act of 1990: An analysis of the victim reporting practices of college and university students. Crime \& Delinquency, 43(2), 148-168.

Stevens, M. L. (2009). Creating a class. Harvard University Press.

Thacher, D. (2008). The rise of criminal background screening in rental housing. Law \& Social Inquiry, 33(1), 5-30.

The Common Application. (2018, August 19). Change to Criminal History Question for 20192020 Application Year [Text]. Retrieved June 7, 2019, from The Common Application website: https://www.commonapp.org/whats-appening/application-updates/changecriminal-history-question-2019-2020-application-year

Tilcsik, A. (2011). Pride and prejudice: Employment discrimination against openly gay men in the United States. American Journal of Sociology, 117(2), 586-626.

Todd, J. R. (2004). It's Not My Problem: How Workplace Violence and Potential Employer Liability Lead to Employment Discrimination of Ex-Convicts. Arizona State Law Journal, 36, 725.

Travis, J., Western, B., \& National Research Council (U.S.) (Eds.). (2014). The growth of incarceration in the United States: exploring causes and consequences. Washington, D.C: The National Academies Press.

Turner, M. A. (1999). Mortgage lending discrimination: A review of existing evidence. Retrieved from

http://webarchive.urban.org/publications/url.cfm?renderforprint=1\&ID=309090\&buildsta tic $=1$

Uggen, C. (2000). Work as a turning point in the life course of criminals: A duration model of age, employment, and recidivism. American Sociological Review, 529-546. 
Uggen, C., Horowitz, V., \& Stewart, R. (2017). Public Criminology and Criminologists with Records. The Criminologist, 42, 3-7.

Uggen, C., \& Stewart, R. (2014). Piling on: Collateral consequences and community supervision. Minn. L. Rev., 99, 1871.

Uggen, C., Vuolo, M., Lageson, S., Ruhland, E., \& Whitham, H. K. (2014). The Edge of Stigma: An Experimental Audit of the Effects of Low-Level Criminal Records on Employment. Criminology, 52(4), 627-654.

University of North Carolina. (2004). Task Force on the Safety of the Campus Community: Final Report. Retrieved from http://counsel.cua.edu/res/docs/final-safety-task-force-report.pdf

U.S. Bureau of Labor Statistics. (2017, October 24). Employment Projections. Retrieved November 26, 2017, from Unemployment rates and earnings by educational attainment website: https://www.bls.gov/emp/ep_chart_001.htm

U.S. Department of Education. (2016). Beyond the Box: Increasing Access to Higher Education for Justice-Involved Individuals. Retrieved from https://www2.ed.gov/documents/beyond-the-box/guidance.pdf

van Dinther, M., Dochy, F., \& Segers, M. (2011). Factors affecting students' self-efficacy in higher education. Educational Research Review, 6(2), 95-108.

Vuolo, M., Lageson, S., \& Uggen, C. (2017). Criminal Record Questions in the Era of "Ban the Box." Criminology \& Public Policy, 16(1), 139-165. https://doi.org/10.1111/17459133.12250

Vuolo, M., Uggen, C., \& Lageson, S. (2016). Statistical power in experimental audit studies: Cautions and calculations for matched tests with nominal outcomes. Sociological Methods \& Research, 45(2), 260-303.

Vuolo, M., Uggen, C., \& Lageson, S. (2018). To match or not to match? Statistical and substantive considerations in audit design and analysis. In S. M. Gaddis (Ed.), Audit Studies: Behind the Scenes with Theory, Method, and Nuance (pp. 119-140). Springer International Publishing.

Wakefield, S., \& Wildeman, C. (2013). Children of the prison boom: Mass incarceration and the future of American inequality. Oxford University Press.

Weichselbaumer, D. (2015). Testing for discrimination against lesbians of different marital status: A field experiment. Industrial Relations: A Journal of Economy and Society, 54(1), 131-161.

Weichselbaumer, D. (2016). Discrimination against female migrants wearing headscarves.

Weissman, M., Rosenthal, A., Warth, P., Wolf, E., \& Messina-Yauchzy, M. (2010). The Use of Criminal History Records in College Admissions Reconsidered. Retrieved from Center for Community Alternatives website: http://www.communityalternatives.org/pdf/Reconsidered-criminal-hist-recs-in-collegeadmissions.pdf 
Western, B. (2002). The impact of incarceration on wage mobility and inequality. American Sociological Review, 526-546.

Wheelock, D. (2005). Collateral consequences and racial inequality: Felon status restrictions as a system of disadvantage. Journal of Contemporary Criminal Justice, 21(1), 82-90.

Wissoker, D. A., Zimmermann, W., \& Galster, G. C. (1998). Testing for discrimination in home insurance. Retrieved from Urban Institute Washington, DC website: http://www.urban.org/sites/default/files/publication/67051/307555-Testing-forDiscrimination-in-Home-Insurance.pdf

Yinger, J. (1998). Evidence on discrimination in consumer markets. The Journal of Economic Perspectives, 12(2), 23-40. 
Table 1. Share of Colleges with Criminal History Questions (CHQs) on their Applications, by Institutional Characteristics $(\mathbf{N}=\mathbf{1 , 3 5 0})$

\begin{tabular}{lrr}
\hline Variable & $\mathrm{N}$ & $\mathrm{CHQs}$ \\
\hline Total & 1,350 & $71.6 \%$ \\
Competitiveness & & \\
Most Competitive & 89 & $89.9 \%$ \\
Highly Competitive & 98 & $82.7 \%$ \\
Very Competitive & 304 & $81.3 \%$ \\
Competitive & 625 & $68.3 \%$ \\
Less Competitive & 175 & $64.0 \%$ \\
$\quad$ Non-Competitive & 59 & $33.9 \%$ \\
Institution Type & & \\
$\quad$ Private & 501 & $58.1 \%$ \\
$\quad$ Public & 849 & $79.6 \%$ \\
Crime & & \\
Lower Crime & 628 & $65.9 \%$ \\
Higher Crime & 722 & $76.6 \%$ \\
Consider Race in Admissions & & \\
No/Unknown & 991 & $67.6 \%$ \\
Yes & 359 & $82.7 \%$ \\
Setting & & \\
City & 627 & $70.8 \%$ \\
Suburb & 326 & $77.6 \%$ \\
Town/Rural & 397 & $68.0 \%$ \\
Large & & \\
Medium & 263 & $59.7 \%$ \\
Small & 388 & $75.5 \%$ \\
Very Small & 529 & $76.4 \%$ \\
Size & 170 & $66.5 \%$ \\
\hline
\end{tabular}

${ }^{\mathrm{a}}$ Higher crime (10 or more) and lower crime (less than 10) refer to Clery Act reported crimes per 1,000 students over the previous 3 years. 
Table 2. Descriptive Statistics of Colleges by Competitiveness and Sample (2015-2016)

\begin{tabular}{|c|c|c|c|c|c|c|c|c|c|}
\hline & \multicolumn{7}{|c|}{ Barron's Competitiveness Levels } & \multirow{2}{*}{$\begin{array}{r}\text { Sampling } \\
\text { Frame }\end{array}$} & \multirow{2}{*}{$\begin{array}{r}\text { Audit } \\
\text { Sample }\end{array}$} \\
\hline & Most & Highly & Very & Comp & Less & Non & Total & & \\
\hline$N$ of Colleges & 89 & 98 & 304 & 625 & 175 & 59 & 1,350 & 1,163 & 280 \\
\hline Total Enrolled Students & 575,519 & 880,708 & $2,159,039$ & $3,534,908$ & 706,617 & 256,877 & $8,113,668$ & $6,657,441$ & $1,388,983$ \\
\hline Public & $10.1 \%$ & $32.7 \%$ & $31.3 \%$ & $40.3 \%$ & $46.9 \%$ & $52.5 \%$ & $37.1 \%$ & $39.6 \%$ & $37.5 \%$ \\
\hline Acceptance Rate ${ }^{a}$ & $26.0 \%$ & $53.1 \%$ & $67.4 \%$ & $69.6 \%$ & $70.0 \%$ & $69.2 \%$ & $64.9 \%$ & $69.1 \%$ & $70.8 \%$ \\
\hline Criminal History Required & $89.9 \%$ & $82.7 \%$ & $81.3 \%$ & $68.3 \%$ & $64.0 \%$ & $33.9 \%$ & $71.6 \%$ & $69.3 \%$ & $71.8 \%$ \\
\hline High Crime $^{\mathrm{b}}$ & $82.0 \%$ & $64.3 \%$ & $51.6 \%$ & $48.5 \%$ & $55.4 \%$ & $49.2 \%$ & $53.5 \%$ & $50.4 \%$ & $47.9 \%$ \\
\hline Race Considered & $92.1 \%$ & $72.4 \%$ & $36.8 \%$ & $13.0 \%$ & $7.4 \%$ & $0.0 \%$ & $26.6 \%$ & $17.7 \%$ & $11.4 \%$ \\
\hline \multicolumn{10}{|l|}{ ACT Composite } \\
\hline 75th percentile ${ }^{a}$ & 33.0 & 30.3 & 27.3 & 24.5 & 22.4 & 22.4 & 25.8 & 24.9 & 24.3 \\
\hline 25 th percentile $^{\mathrm{a}}$ & 29.6 & 25.5 & 21.9 & 19.1 & 17.3 & 16.7 & 20.7 & 19.6 & 18.9 \\
\hline Undergraduates, Black & $5.5 \%$ & $4.9 \%$ & $8.5 \%$ & $14.6 \%$ & $25.4 \%$ & $26.3 \%$ & $13.8 \%$ & $15.2 \%$ & $12.5 \%$ \\
\hline Undergraduates, White & $53.4 \%$ & $62.3 \%$ & $63.8 \%$ & $59.5 \%$ & $46.6 \%$ & $44.2 \%$ & $57.9 \%$ & $57.9 \%$ & $63.3 \%$ \\
\hline Grad. Rate (150\% Time) & $88.1 \%$ & $77.3 \%$ & $62.9 \%$ & $49.2 \%$ & $39.8 \%$ & $29.6 \%$ & $54.8 \%$ & $50.4 \%$ & $46.9 \%$ \\
\hline Pell Recipients & $15.9 \%$ & $21.7 \%$ & $30.0 \%$ & $38.4 \%$ & $46.2 \%$ & $49.2 \%$ & $35.3 \%$ & $37.9 \%$ & $38.0 \%$ \\
\hline \multicolumn{10}{|l|}{ Setting } \\
\hline City & $56.2 \%$ & $51.0 \%$ & $52.6 \%$ & $42.7 \%$ & $42.3 \%$ & $44.1 \%$ & $46.4 \%$ & $45.3 \%$ & $34.3 \%$ \\
\hline Suburb & $30.3 \%$ & $27.6 \%$ & $23.7 \%$ & $24.6 \%$ & $21.1 \%$ & $15.3 \%$ & $24.1 \%$ & $23.4 \%$ & $27.5 \%$ \\
\hline Town/Rural & $13.5 \%$ & $21.4 \%$ & $23.7 \%$ & $32.6 \%$ & $36.6 \%$ & $40.7 \%$ & $29.4 \%$ & $31.3 \%$ & $38.2 \%$ \\
\hline \multicolumn{10}{|l|}{ Size } \\
\hline Large & $37.1 \%$ & $30.6 \%$ & $23.7 \%$ & $17.4 \%$ & $7.4 \%$ & $10.2 \%$ & $19.5 \%$ & $17.2 \%$ & $15.0 \%$ \\
\hline Medium & $16.9 \%$ & $21.4 \%$ & $29.3 \%$ & $31.0 \%$ & $32.6 \%$ & $20.3 \%$ & $28.7 \%$ & $30.3 \%$ & $28.6 \%$ \\
\hline Small & $41.6 \%$ & $40.8 \%$ & $38.2 \%$ & $38.2 \%$ & $40.0 \%$ & $45.8 \%$ & $39.2 \%$ & $38.9 \%$ & $40.7 \%$ \\
\hline Very small & $4.5 \%$ & $7.1 \%$ & $8.9 \%$ & $13.3 \%$ & $20.0 \%$ & $23.7 \%$ & $12.6 \%$ & $13.7 \%$ & $15.7 \%$ \\
\hline
\end{tabular}

${ }^{a}$ Because some colleges choose not to provide data for information not required as part of their admissions process, those colleges are not included in these categories.

${ }^{\mathrm{b}}$ High crime is defined as 10 or more Clery Act reported crimes per 1,000 students over previous 3 years.

Sources: Barron's Profiles of American Colleges (2015); Integrated Postsecondary Education Data System (2015); College Board's Annual Survey of Colleges (2017); U.S. Department of Education 
Table 3. Distribution of Accepted Applications for Each Paired Audit and McNemar's Test

\begin{tabular}{|c|c|c|c|c|}
\hline \multirow[b]{2}{*}{ Black $(n=149)$} & & \multicolumn{3}{|c|}{ Felony Record } \\
\hline & & Accepted & Not Accepted & Total \\
\hline \multirow[t]{3}{*}{ No Felony Record } & Accepted & .673 & .220 & .893 \\
\hline & Not Accepted & .060 & .047 & .107 \\
\hline & Total & .733 & .267 & 1.000 \\
\hline \multicolumn{5}{|c|}{ McNemar's Test: $p_{1+}-p_{+1}=.16 ; \mathrm{OR}=3.667 ; \mathrm{SE}=.041 ; p<.001$ (two-tailed); $\chi 2=13.71$} \\
\hline & & \multicolumn{3}{|c|}{ Felony Record } \\
\hline \multicolumn{2}{|l|}{ White (n=130) } & Accepted & Not Accepted & Total \\
\hline \multirow[t]{3}{*}{ No Felony Record } & Accepted & .738 & .169 & .907 \\
\hline & Not Accepted & .023 & .069 & .092 \\
\hline & Total & .761 & .238 & 1.000 \\
\hline \multicolumn{5}{|c|}{ McNemar's Test: $p_{1+}-p_{+1}=.146 ; \mathrm{OR}=7.333 ; \mathrm{SE}=.036 ; p<.001$ (two-tailed) $\chi^{2}=14.44$} \\
\hline & & \multicolumn{3}{|c|}{ Felony Record } \\
\hline Total $(n=279)$ & & Accepted & Not Accepted & Total \\
\hline \multirow[t]{3}{*}{ No Felony Record } & Accepted & .704 & .196 & .900 \\
\hline & Not Accepted & .043 & .057 & .100 \\
\hline & Total & .746 & .254 & 1.000 \\
\hline
\end{tabular}

McNemar's Test: $p_{1+}-p_{+1}=.154 ; \mathrm{OR}=4.583 ; \mathrm{SE}=.056 ; p<.001$ (two-tailed); $\chi 2=27.6$

Abbreviations: $p_{1+}=$ proportion in row $1 ; p_{+1}=$ proportion in column $1 ; \mathrm{SE}=$ standard error; $\mathrm{OR}=$ odds ratio. 
Table 4. Logistic Mixed-Effects Regression for College Acceptance

\begin{tabular}{|c|c|c|c|c|c|c|c|c|c|c|}
\hline \multirow{2}{*}{$\begin{array}{l}N \text { (colleges/applications) } \\
\text { Effects }\end{array}$} & \multicolumn{3}{|c|}{ Black (150/300) } & \multicolumn{3}{|c|}{ White (130/260) } & \multicolumn{4}{|c|}{ Pooled $(280 / 560)$} \\
\hline & Model 1 & Model 2 & Model 3 & Model 4 & Model 5 & Model 6 & Model 7 & Model 8 & Model 9 & Model 10 \\
\hline \multicolumn{11}{|l|}{ Fixed effects } \\
\hline \multirow[t]{2}{*}{ Felony record } & $-1.30 * * *$ & $-1.35 * * *$ & -.75 & $-1.97 * * *$ & $-2.02 * *$ & $-1.46^{*}$ & $-1.52 * * *$ & $-1.52 * * *$ & $-1.52 * * *$ & $-.93 *$ \\
\hline & $(.38)$ & $(.39)$ & $(.47)$ & $(.60)$ & $(.63)$ & $(.75)$ & $(.32)$ & $(.32)$ & $(.32)$ & $(.39)$ \\
\hline \multirow{2}{*}{$\begin{array}{l}\text { High crime } \\
\qquad(10+/ 1,000 \text { students })\end{array}$} & & -.18 & .90 & & -.21 & .64 & & & -.15 & .87 \\
\hline & & $(.41)$ & $(.71)$ & & $(.70)$ & $(1.02)$ & & & $(.35)$ & $(.58)$ \\
\hline \multirow{2}{*}{$\begin{array}{l}\text { Felony record } * \text { High crime } \\
\text { (Interaction) }\end{array}$} & & & $-1.60 *$ & & & -1.21 & & & & $-1.51 *$ \\
\hline & & & $(.81)$ & & & $(1.06)$ & & & & $(.63)$ \\
\hline \multirow[t]{2}{*}{ Black } & & & & & & & & -.24 & -.32 & -.34 \\
\hline & & & & & & & & $(.35)$ & $(.34)$ & $(.36)$ \\
\hline \multirow[t]{2}{*}{ Race/Ethnicity Considered } & & -.64 & -.73 & & .60 & .59 & & & -.10 & -.12 \\
\hline & & $(.55)$ & $(.61)$ & & $(1.05)$ & $(1.06)$ & & & $(.50)$ & $(.54)$ \\
\hline \multirow{4}{*}{$\begin{array}{l}\text { Criminal History } \\
\text { Disclosure Question } \\
\text { Public (ref: Private) }\end{array}$} & & $-1.38 * *$ & $-1.48 * *$ & & $-1.74+$ & $-1.77+$ & & & $-1.34 * *$ & $-1.41 * *$ \\
\hline & & $(.52)$ & $(.56)$ & & $(.95)$ & $(.96)$ & & & $(.45)$ & $(.48)$ \\
\hline & & -.59 & -.64 & & $2.40^{*}$ & $2.39+$ & & & .64 & .68 \\
\hline & & $(.56)$ & $(.60)$ & & $(1.22)$ & $(1.22)$ & & & $(.51)$ & $(.53)$ \\
\hline \multirow{2}{*}{$\begin{array}{l}\text { Competitiveness: Moderate } \\
\text { (ref: Less) }\end{array}$} & & 1.32 & 1.41 & & -1.10 & -1.11 & & & .12 & .13 \\
\hline & & $(.96)$ & $(1.04)$ & & $(1.18)$ & (1.19) & & & $(.66)$ & $(.70)$ \\
\hline \multirow{2}{*}{$\begin{array}{l}\text { Competitiveness: High } \\
\text { (ref: Less) }\end{array}$} & & .22 & .23 & & .73 & .74 & & & .44 & .46 \\
\hline & & $(.51)$ & $(.54)$ & & $(.90)$ & $(.90)$ & & & $(.44)$ & $(.46)$ \\
\hline \multirow{2}{*}{$\begin{array}{l}\text { City } \\
\text { (ref: Rural) }\end{array}$} & & .02 & .02 & & -.27 & -.27 & & & -.13 & -.14 \\
\hline & & $(.45)$ & $(.48)$ & & $(.87)$ & $(.87)$ & & & $(.42)$ & $(.44)$ \\
\hline \multirow{2}{*}{$\begin{array}{l}\text { Suburban } \\
\quad \text { (ref: Rural) }\end{array}$} & & -.03 & -.02 & & -.70 & -.66 & & & -.24 & -.23 \\
\hline & & $(.48)$ & $(.52)$ & & $(.92)$ & $(.92)$ & & & $(.43)$ & $(.46)$ \\
\hline
\end{tabular}

Numbers in parentheses are standard errors.

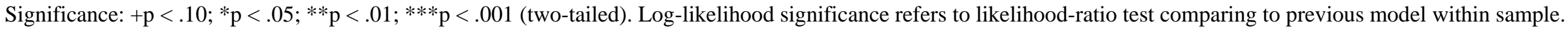


Table 4. Cont.

\begin{tabular}{|c|c|c|c|c|c|c|c|c|c|c|}
\hline \multirow{2}{*}{$\begin{array}{l}N \text { (colleges/applications) } \\
\text { Effects }\end{array}$} & \multicolumn{3}{|c|}{ Black $(150 / 300)$} & \multicolumn{3}{|c|}{ White (130/260) } & \multicolumn{4}{|c|}{ Pooled $(280 / 560)$} \\
\hline & Model 1 & Model 2 & Model 3 & Model 4 & Model 5 & Model 6 & Model 7 & Model 8 & Model 9 & Model 10 \\
\hline \multirow{2}{*}{$\begin{array}{l}\text { Size: Large } \\
\text { (ref: Very Small) }\end{array}$} & & .64 & .73 & & $-4.29 *$ & $-4.28 *$ & & & -1.30 & -1.34 \\
\hline & & $(.90)$ & $(.96)$ & & $(1.93)$ & $(1.93)$ & & & $(.81)$ & $(.86)$ \\
\hline \multirow{2}{*}{$\begin{array}{l}\text { Size: Medium } \\
\text { (ref: Very Small) }\end{array}$} & & .44 & .45 & & -1.95 & -1.92 & & & -.66 & -.70 \\
\hline & & $(.71)$ & $(.77)$ & & $(1.42)$ & $(1.42)$ & & & $(.63)$ & $(.67)$ \\
\hline \multirow{2}{*}{$\begin{array}{l}\text { Size: Small } \\
\quad \text { (ref: Very Small) }\end{array}$} & & .69 & .75 & & -.52 & -.52 & & & .04 & .04 \\
\hline & & $(.59)$ & $(.64)$ & & $(1.22)$ & $(1.22)$ & & & $(.55)$ & $(.58)$ \\
\hline \multirow{2}{*}{$\begin{array}{l}\text { Undergraduate enrollment } \\
\text { Black (proportion) }\end{array}$} & & -2.79 & -3.00 & & 4.55 & 4.41 & & & .41 & .41 \\
\hline & & $(2.43)$ & $(2.64)$ & & $(3.93)$ & $(3.91)$ & & & $(1.89)$ & $(2.00)$ \\
\hline \multirow{2}{*}{$\begin{array}{l}\text { Pell Grant recipients } \\
\text { (proportion) }\end{array}$} & & $6.74 *$ & $7.27 *$ & & -4.28 & -3.90 & & & 1.63 & 1.79 \\
\hline & & $(3.01)$ & $(3.25)$ & & $(4.78)$ & $(4.77)$ & & & $(2.38)$ & $(2.51)$ \\
\hline \multirow[t]{2}{*}{ Six-Year Graduation rate } & & $-3.90+$ & $-4.27+$ & & -.64 & -.60 & & & -2.50 & -2.70 \\
\hline & & $(2.24)$ & $(2.46)$ & & $(3.54)$ & $(3.56)$ & & & $(1.87)$ & $(1.98)$ \\
\hline \multirow[t]{2}{*}{ More qualified tester pair } & & $.97^{*}$ & $1.04 *$ & & $1.35+$ & $1.36+$ & & & $1.15 * * *$ & $1.20 * *$ \\
\hline & & $(.38)$ & $(.42)$ & & $(.72)$ & $(.72)$ & & & $(.35)$ & $(.37)$ \\
\hline \multirow[t]{2}{*}{ First to apply } & & -.17 & -.15 & & .60 & .60 & & & .12 & .14 \\
\hline & & $(.35)$ & $(.36)$ & & $(.54)$ & $(.54)$ & & & $(.28)$ & $(.29)$ \\
\hline \multirow[t]{2}{*}{ Month submitted } & & .11 & .14 & & .12 & .11 & & & .09 & .10 \\
\hline & & $(.14)$ & $(.15)$ & & $(.29)$ & $(.30)$ & & & $(.13)$ & $(.14)$ \\
\hline \multirow[t]{2}{*}{ (Intercept) } & $2.54 * * *$ & 2.10 & 1.74 & $4.25 * * *$ & $6.09+$ & 5.61 & $3.11 * * *$ & $3.25 * * *$ & $3.79 *$ & $3.55^{*}$ \\
\hline & $(.43)$ & $(1.82)$ & $(1.95)$ & $(.95)$ & $(3.47)$ & $(3.49)$ & $(.41)$ & $(.47)$ & $(1.67)$ & $(1.76)$ \\
\hline \multicolumn{11}{|l|}{ Random Effects } \\
\hline \multirow[t]{2}{*}{ College (variance) } & 1.18 & .26 & .57 & $7.05+$ & 4.13 & 4.20 & $2.82 *$ & $2.83 *$ & $1.69+$ & $2.12+$ \\
\hline & $(1.00)$ & $(.69)$ & $(.87)$ & $(4.05)$ & $(2.95)$ & $(2.98)$ & $(1.25)$ & $(1.25)$ & $(.96)$ & $(1.14)$ \\
\hline Log-likelihood & -136.70 & $-117.20 * *$ & $-115.00 *$ & -103.30 & $-87.19^{*}$ & -86.58 & -242.30 & -242.10 & $-217.00 * *$ & $-214.00 *$ \\
\hline
\end{tabular}

Numbers in parentheses are standard errors.

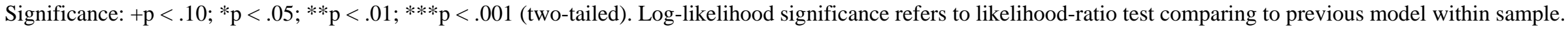


Figure 1. Acceptance Rate by Race and Felony Record

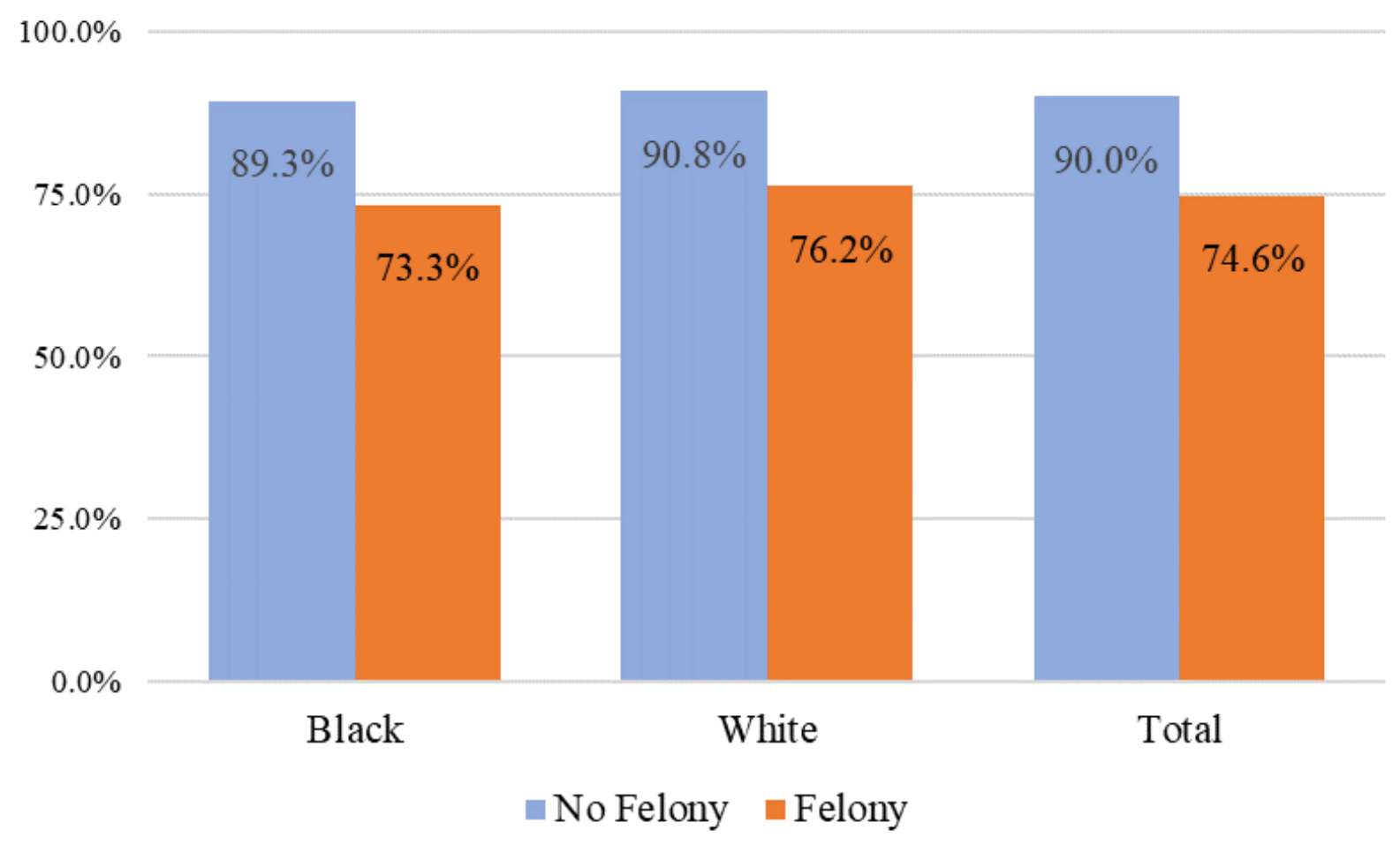


Figure 2. Predicted Probabilities of Admission by Race for Record Status and Crime Rate

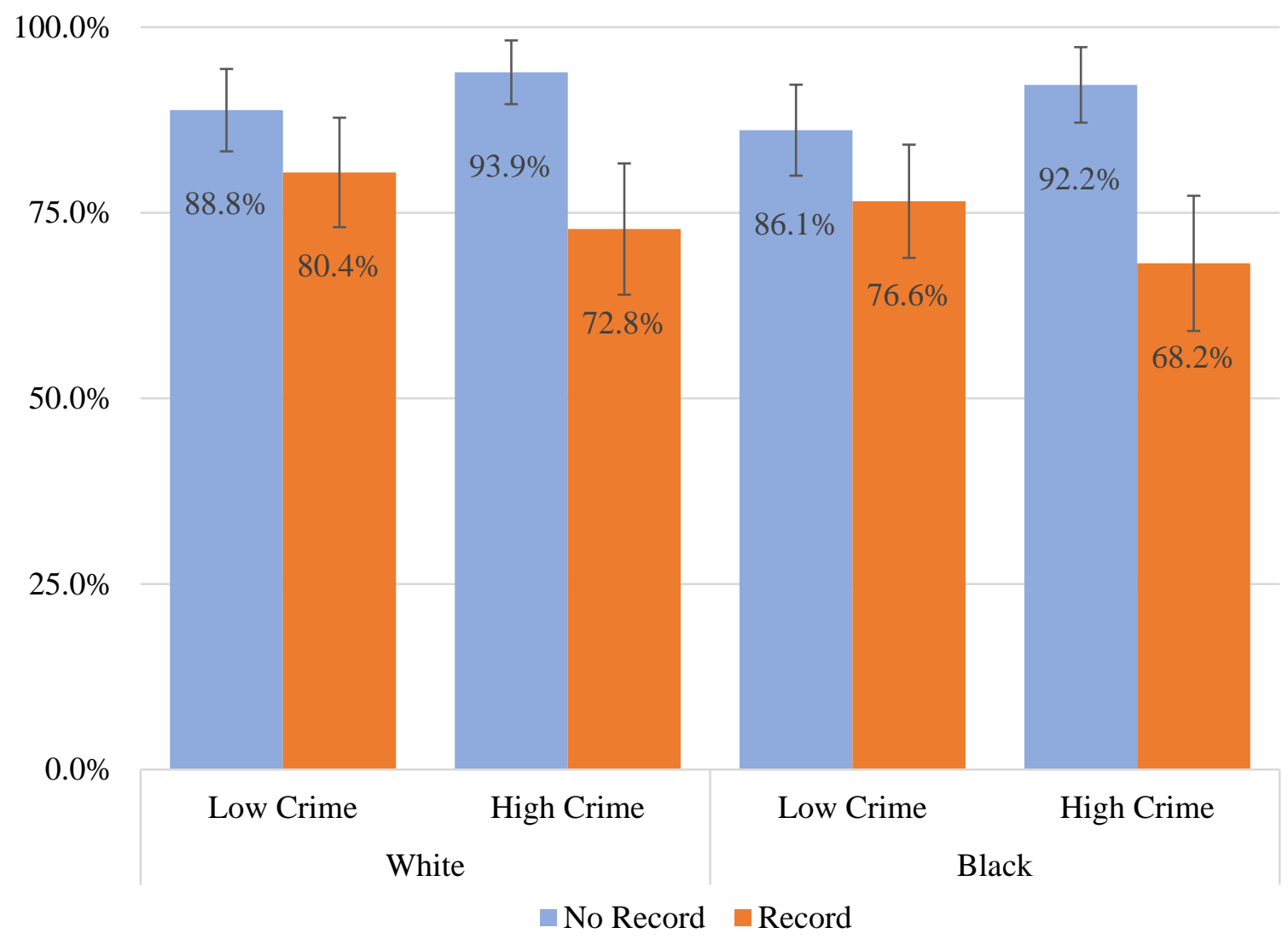

Note: Error bars indicate 95\% confidence intervals 
Figure 3. Acceptance Rate by Criminal History Application Question and Felony Record

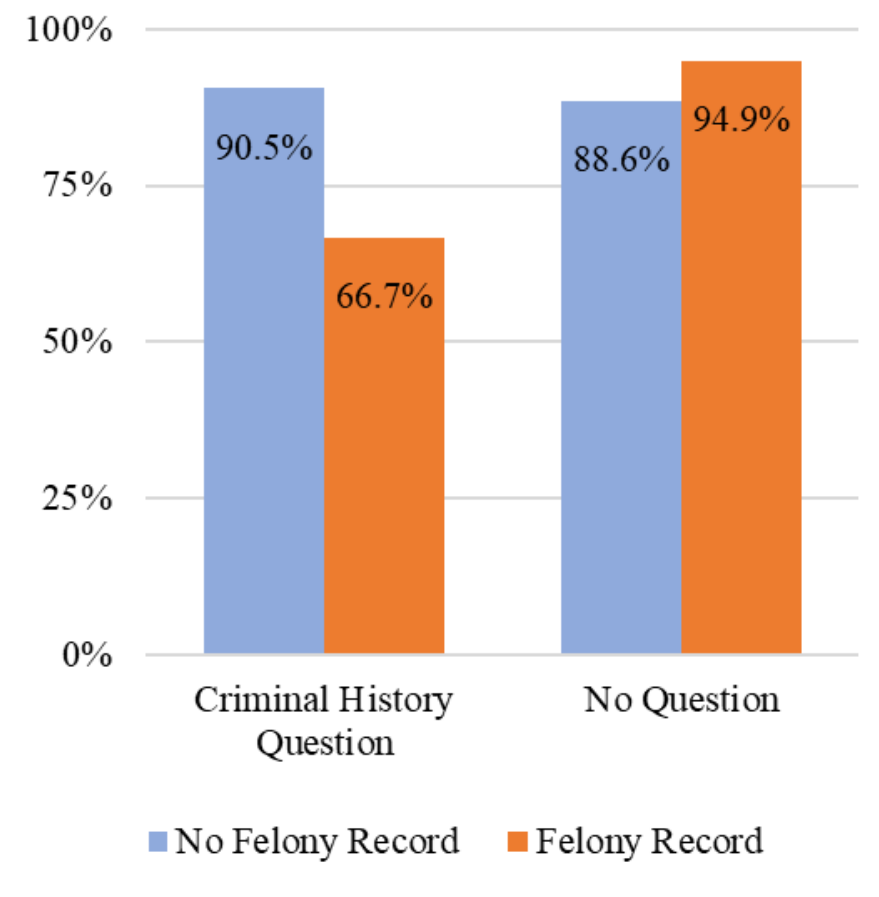


Figure 4. Predicted Probabilities of Acceptance for No-Record Applicants by Race $(n=330)$

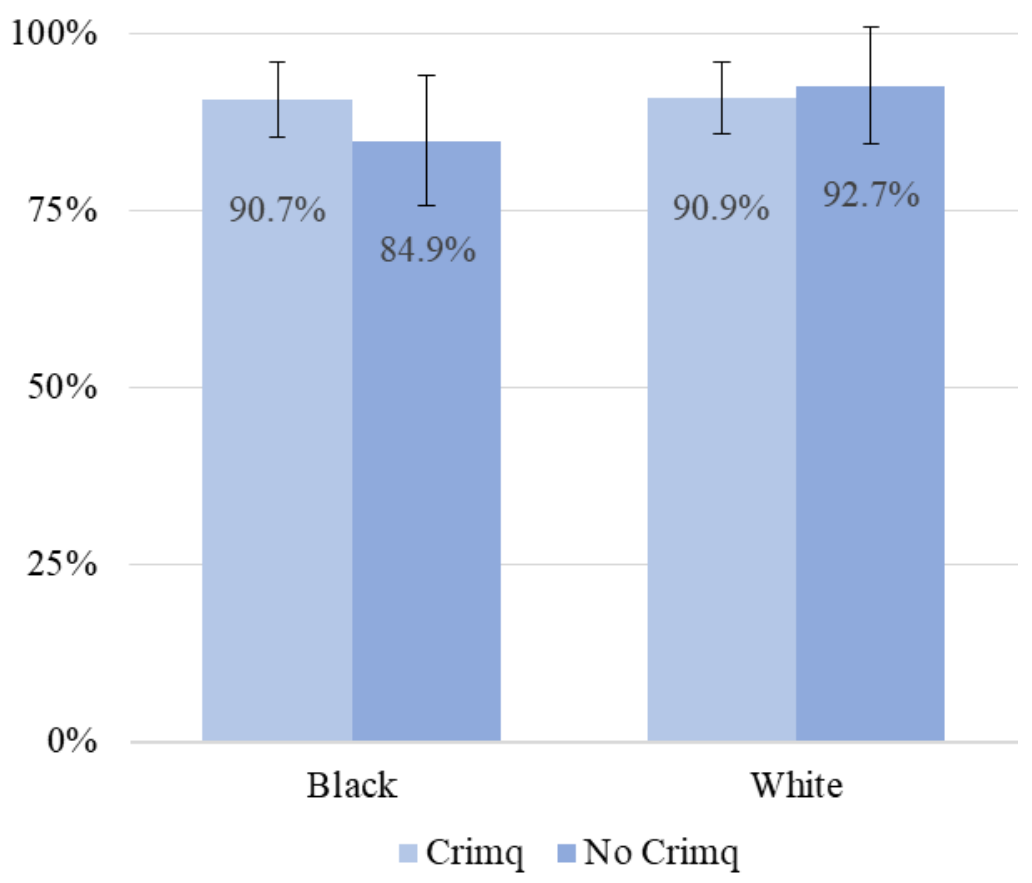

Note: Error bars indicate $95 \%$ confidence intervals 


\section{APPENDIX 1 - TESTER NAMES AND RACE}

To determine whether the names of our testers would be strongly indicative of the testers' racial identity, we followed the guidance provided by Gaddis (2017). We randomly survey 200 workers on Mechanical Turk using a branched survey design and a list of twenty first names: our four testers' names, six names typically associated with Black men, six typically associated with White men, and four that were relatively racially ambiguous (see Figure A1). We asked respondents first whether they associated the name with a particular racial group; if yes, we then asked respondents to identify which racial group (Asian, Black, Latino, White, Other). Those that the respondent did not associate with a specific racial group were categorized as "None," while those categorized as Asian, Latino, or Other were collapsed into "Other" for the purposes of Figure A1. While two of our testers' names did appear to have slightly more racial salience, nearly half of our survey respondents did not associate specific race groups with our four of our names. Thus, tester names alone are not likely to convey strong racial signals. 
Figure A1. Comparison of Racial Associations of Tester Names by 200 Mechanical Turk Workers

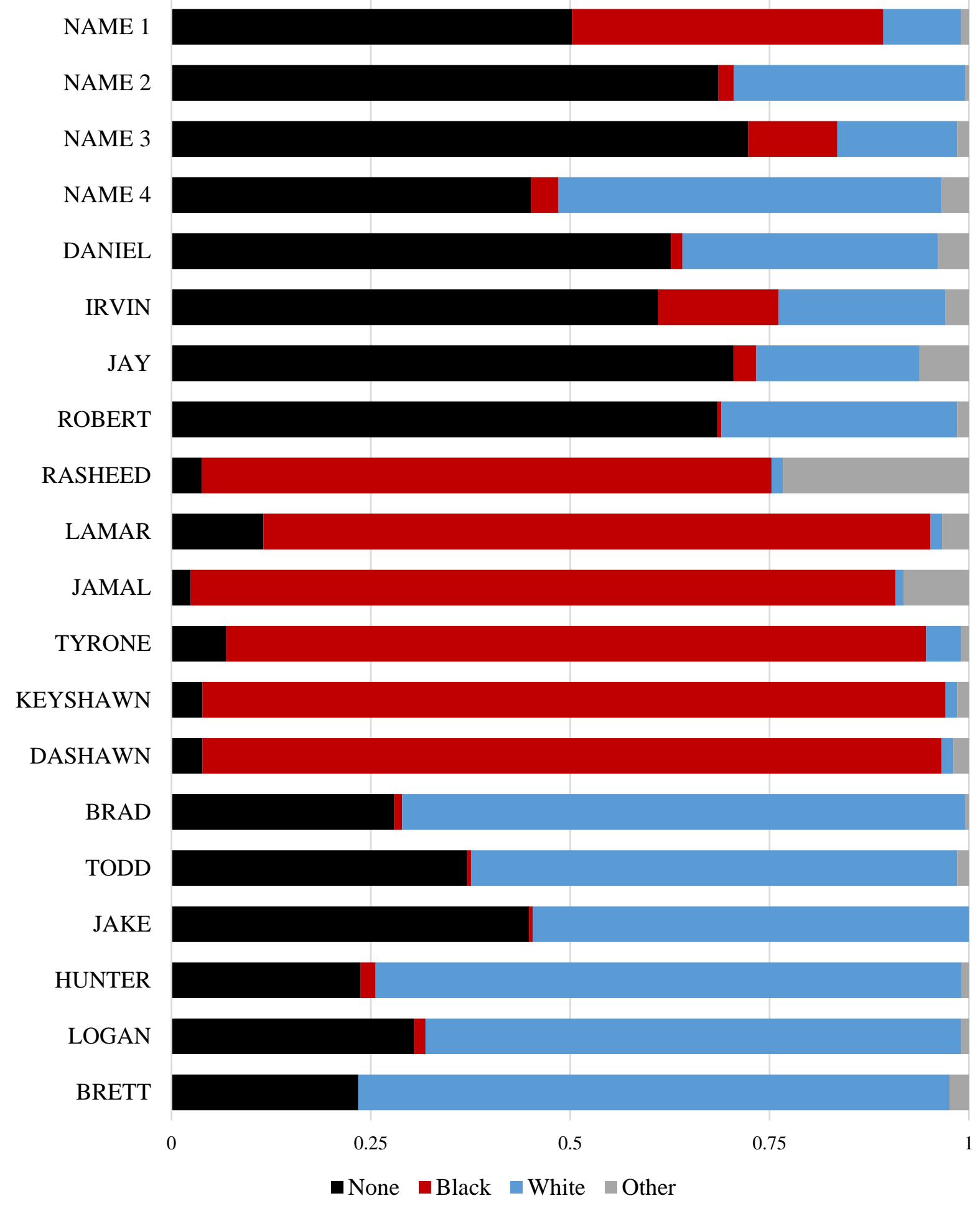




\section{APPENDIX 2 - THE MODIFIED AUDIT AND FUTURE RESEARCH}

Here we offer advice for future researchers about how the modified audit approach used in this study could be adapted to other questions. We came to this topic with two specific questions: what effect does a criminal record have on college admissibility, and to what extent does race mediate that effect. The topic was worthy of investigation, but the context presented a difficult situation for a field experiment that relies on total fabrication. The modified audit is not without its limitations, but we hope the design presented above demonstrates the viability of an experimental approach that foregoes the use of fabricated materials and instead uses real records from real participants. While adapting the modified audit requires additional layers of planning and strategizing, it also offers several benefits and opens doors to areas of inquiry that might not otherwise be available. Although outside of the scope of what we present here, using this modified audit design allowed us to collect additional data, in the form of thousands of emails, postal mail, text messages, and other materials that can be used to answer questions that the quantitative results are not suited for, such as how the application process differs for applicants with records. Here, we offer three pieces of advice to consider when adapting the modified audit to another context.

First, in our experience, this approach requires a significant amount of design decisionmaking and, thus, requires necessary tradeoffs. Researchers will be continually confronted with forks in the road, many of which will be unexpected, and different options or paths will deliver different benefits and drawbacks. To maintain consistency and guide design choices, we suggest future researchers be deliberate in the pre-design phase of the project by outlining the goals of the study and processes they are emulating. For example, for this study we pursued a design that was as realistic as possible, reflecting the real application experiences and behaviors of 
applicants with profiles like our testers, while maintaining internal integrity. This informed all of our choices, including how we defined our sampling frame (focusing on four-year colleges, including colleges that do and do not require criminal history information, not including elite or near-elite colleges), how we conveyed race (checking the race box on the application, not including race-based affinity groups that would likely be unrealistic for students like our testers), and of course the use of real records (average students instead high-achieving students, low-level felony records that are common for this age group). While not determinative or fool-proof, establishing goals and ideals ahead of time will provide valuable guidance in the design phase and particularly when in the field and unforeseen circumstances arise.

Second, we suggest thinking through how initial barriers might be turned into advantages. In the college admissions audit, we were not able to fabricate standardized test scores, high school transcripts, or criminal records, which led to us enlist real participants with real records. Of course, using real records opens this context for study, which would otherwise be inaccessible for a field experiment, and we were far less concerned of arousing suspicion than we would have been if we had used fabricated records. When approaching the matching process, we recognized that it would be impossible to perfectly match any two people's educational backgrounds, but we also had control over how to match our testers. Since we could not create perfectly matched pairs, we purposely created mismatched pairs that would thus produce a conservative estimate of criminal record discrimination by intentionally building in differences between our testers within each pair. We did this by ensuring our Record testers were always more qualified students academically within each pair when creating our matches. But an extension of this design could amplify the asymmetry when creating matches to find, for example, how large deficiencies in an applicant's academic background must be in order to impede college admissibility at levels on 
par with the discriminatory effects of a criminal record. Moreover, while the records could not be randomized, we could still randomize elements such as race, essays, and other information that could be similarly leverage in future field experiments.

Finally, we strongly urge future researchers to pay close attention to the ethics involved with using real records from real participants. The protection of the participants who willingly allow their information to be used for research should certainly prioritized. This includes not just current impacts of the project but also any long-term effects. We took several steps to address these ethical considerations. When presenting the project to potential participants, we spent a lot of time discussing the possible ramifications (e.g., if a participant decided to apply at one of the colleges in the sample at some point in the future). This in part motivated us to not include colleges in their home state in our sample. While our participants told us that they were not planning on moving out of state or going to college any time soon, we nevertheless established contingency plans if problems arose. Moreover, we sought to mitigate future issues by withdrawing our applicants' applications immediately after receiving any notifications of acceptance while in the field because colleges typically only retain admissions records of applicants who do not attend for a few years. This strategy also ensured that our testers would not be taking a seat that could have otherwise gone to another student. 